IZA DP No. 8695

Beyond the Average: Peer Heterogeneity and Intergenerational Transmission of Education

Tanika Chakraborty

Olga Nottmeyer

Simone Schüller

Klaus F. Zimmermann

December 2014 


\title{
Beyond the Average: Peer Heterogeneity and Intergenerational Transmission of Education
}

\author{
Tanika Chakraborty \\ Indian Institute of Technology, Kanpur and IZA \\ Olga Nottmeyer \\ IZA \\ Simone Schüller \\ FBK-IRVAPP and IZA \\ Klaus F. Zimmermann \\ IZA and University of Bonn
}

Discussion Paper No. 8695

December 2014

\author{
IZA \\ P.O. Box 7240 \\ 53072 Bonn \\ Germany \\ Phone: +49-228-3894-0 \\ Fax: +49-228-3894-180 \\ E-mail: iza@iza.org
}

Any opinions expressed here are those of the author(s) and not those of IZA. Research published in this series may include views on policy, but the institute itself takes no institutional policy positions. The IZA research network is committed to the IZA Guiding Principles of Research Integrity.

The Institute for the Study of Labor (IZA) in Bonn is a local and virtual international research center and a place of communication between science, politics and business. IZA is an independent nonprofit organization supported by Deutsche Post Foundation. The center is associated with the University of Bonn and offers a stimulating research environment through its international network, workshops and conferences, data service, project support, research visits and doctoral program. IZA engages in (i) original and internationally competitive research in all fields of labor economics, (ii) development of policy concepts, and (iii) dissemination of research results and concepts to the interested public.

IZA Discussion Papers often represent preliminary work and are circulated to encourage discussion. Citation of such a paper should account for its provisional character. A revised version may be available directly from the author. 
IZA Discussion Paper No. 8695

December 2014

\title{
ABSTRACT
}

\section{Beyond the Average: Peer Heterogeneity and Intergenerational Transmission of Education}

\begin{abstract}
Estimating the effect of 'ethnic capital' on human capital investment decisions is complicated by the endogeneity of location choice of immigrants and the reflection problem. We exploit a rare immigrant settlement policy in Germany to identify the causal impact of parental peerheterogeneity on the educational outcomes of their children. To identify the direction of peer effect we restrict to no-child-adult-peers who completed their education much before the children in our sample of interest. We find that children of low-educated parents benefit significantly from the presence of high-educated neighbors, with more pronounced effects in more polarized neighborhoods and significant gender heterogeneity. In contrast, we do not find any negative influence coming from the low-educated neighbors. Our estimates are robust to a range of flexible peer definitions. Overall, the findings suggest an increase in parental aspirations as the possible mechanism rather than a direct child-to-child peer effect.
\end{abstract}

JEL Classification: R23, J15, 121

Keywords: education, ethnic capital, Germany, immigrant, peer effects, policy experiment

Corresponding author:

Simone Schüller

FBK-IRVAPP

Via Santa Croce 77

38122 Trento

Italy

E-mail: schueller@fbk.eu

\footnotetext{
* We thank the seminar participants at IIT Kanpur, IZA, FBK-IRVAPP, conference participants at ERSA 2013, RES 2014 and SOLE 2014. We also thank Enrico Rettore and Konstantinos Tatsiramos for helpful comments and suggestions. We are grateful to the Research Data Centre of the Federal Statistical Office (FDZ) for providing us access to and support with the German microcensus data. We are also grateful to the data services of the IDSC of IZA.
} 


\section{Introduction}

An overwhelming proportion of research in labor and migration economics involves the economic assimilation of immigrants and education is unequivocally considered to be the most important facilitator in this process of assimilation. Interest in educational attainment of immigrants has been on the rise in recent decades. This is particularly true for Europe where past research has shown a lack of educational integration of second-generation immigrants from certain ethnicities (Österberg, 2000; Nielsen et al., 2003; Van Ours and Veenman, 2004). Coupled with this, the evidence on low intergenerational education and earnings mobility has led to a widely held belief that immigrants are unlikely to assimilate with the native population (Hammarstedt and Palme, 2006). For instance, a dominant perception in Germany, evident in media, public discourses, popular surveys and opinion polls is that of a failed integration of some immigrant groups.

Evidence from other regions suggests a similar experience. In the US, educational differentials observed between Italians, Scottish, Mexicans and natives in 1910 persisted 60 years later among these groups (Leon, 2005). However, evidence suggests that the rate of intergenerational persistence varies significantly across immigrants from different ethnicities. In Canada, for instance, second-generation immigrants from Mexico and other South American countries show much lower levels of intergenerational mobility compared to Asians and Africans, who fare better than natives in terms of both educational achievements and labor market outcomes (Finnie and Mueller, 2009). ${ }^{1}$ Finnie and Mueller (2009) argue that the differences in intergenerational transmission rates by country of origin, that remain after eliminating demographic and socio-economic factors, stem from cultural differences. In fact, a large section of academic research attributes these differences to nurture, genetic or cultural factors (Crul and Vermeulen, 2003; Black et al., 2005).

However, a second strand of literature points to the importance of childhood environment, in addition to parental influence, in determining education outcomes of children. Borjas (1995) notes that individuals raised in advantageous ethnic environments are more likely to experience better economic outcomes. Presence of ethnic externalities affects the skill acquisition of subsequent immigrant generations and this may lead to a delay in the convergence of ethnic differentials in education. ${ }^{2}$ If indeed 'ethnic capital' explains differences in skill acquisition across generations of

\footnotetext{
${ }^{1}$ Dissimilar convergence rates are also observed across the different Aussiedler ethnicities in Germany which are subject to our study. Figure A1 in the Appendix shows that intergenerational persistence in education varies significantly across immigrants coming from different source countries.

${ }^{2}$ We observe a similar pattern amongst Aussiedler immigrants in Germany. In Figure A2 in the Appendix, children exhibit a higher probability of educational attainment if their ethnic group has a higher fraction of high-educated individuals.
} 
different ethnic groups, then it would provide a rationale for policies that determine the location choice of immigrants at entry. While there is a large literature estimating the impact of residential segregation on labor market outcomes in general, few focus on immigrant children. This is despite the fact that migrant children hold a key position with respect to migrants' long-term economic progression and integration in the host country (Åslund et al., 2011).

Our paper is related to a vast literature estimating the effect of environment on individual labor market outcomes. These include the studies estimating the effect of residential segregation on adult outcomes (Cutler and Glaeser, 1997; Bertrand et al., 2000; Åslund and Fredriksson, 2009, among others), neighborhood segregation on children's education (Angrist and Lang, 2004; Card and Rothstein, 2007; Hanushek et al., 2009, among others), and finally the literature that directly studies the effect of ethnic capital on children's education (Borjas, 1995; Cortes, 2006; Åslund et al., 2011). While Borjas $(1992,1995)$ provides empirical evidence in support of parental peer effects, these estimates do not attempt to identify causality. Since parental skills and average skill levels in the ethnic group may be correlated for a number of reasons, an observed association between ethnic capital and child outcomes is not necessarily causal (Leon, 2005). Åslund et al. (2011) use an exogenous location policy of refugees in Sweden to identify the average effect of the ethnic peer group.

We contribute to this relatively scarce literature on ethnic peer effects in two ways. First, we address the identification challenge by exploiting a policy intervention in Germany that exogenously determines the initial place of residence for certain immigrants. Second, final educational attainment of individuals is an important instrument for policies targeting greater integration of immigrants. However, educational attainment of adolescents could be a joint decision of the parents and the children themselves, driven either by parental aspirations or by the child's own expected returns to education. It becomes difficult to disentangle the two mechanisms when we observe children at ages close to their completion of education. However, identifying the effect of each component is important since policies that aim to improve educational attainment of immigrant children via information provision need to be targeted effectively (Giustinelli, 2010). The context of Germany provides a unique possibility to identify the role played by parental peers in affecting children's education outcomes through the channel of parental aspirations. Since Germany follows a tracking system in lower secondary school, the long-run educational outcome of an individual is strongly correlated with the track he or she ends up in at the age of ten, approximately. Under the assumption that parental influence matters more at early ages, our estimates reflect the effect of 
ethnic peers on parental investment in children. ${ }^{3}$

Third, we estimate the effect of peer heterogeneity, unlike the previous literature on ethnic capital which focuses on either the average effect of the peer group (Borjas, 1995) or only on the fraction of high-educated peers (Åslund et al., 2011). Extreme tails of the peer ability distribution might generate different peer effects, which get muffled when only the effect of the average peer ability is considered (Lavy et al., 2012). Consider three different distributions of peer ability represented by Population-1 (P1), Population-2 (P2) and Population-3 (P3) in Figure 1 and Figure 2. Suppose distributions $\mathrm{P} 1$ and $\mathrm{P} 2$ have the same mean but $\mathrm{P} 1$ has a higher probability mass on the right tail than P2. In the extreme case, P2 could have the entire mass located at the mean. Borjas (1995) implicitly assumes that P1 and P2 would have identical effects. However, it is entirely possible that the relevant peers that affect parental expectations and aspirations are only the very highly educated, located at the right tail of the P2. Next, consider P3 with a higher mean than P1 or P2, but identical to P1 in terms of the mass in the higher tail. Åslund et al. (2011) restrict P3 and P1 to have the same peer effect, which need not be the case since P3 and P1 are not comparable distributions in terms of their masses in the lower tail. In other words, the composition in the lower tail of the distribution might have independent peer effects that get confounded with the higher tail when not controlled for. Our specifications allow the low and high ends of the parental-peer-education distribution to have different effects on the educational attainment of the children.

Figure 1 about here

Figure 2 about here

Finally, previous research uses refugee settlement policies to identify immigrant peer effects. However, refugees form a very specific group that cannot be generalized as regular labor migrants, who are the primary group of interest to policymakers. This study focuses on the particular group of ethnic German immigrants (so-called Aussiedler) to Germany. This group living in large numbers in central and eastern Europe and the former Soviet Union gained the opportunity to immigrate to Germany with the end of the cold war. Using data from the German Socio-Economic Panel (SOEP) we find that ethnic German immigrants, whose migration is mainly motivated by economic opportunities, more closely resemble the group of regular labor migrants. Ethnic Germans are similar to other immigrants in Germany in terms of their reasons to migrate and German language

\footnotetext{
${ }^{3}$ Note that parental investment on children in the case of tracking can happen in multiple ways. Parents might spend more time to teach children at home so that they attain higher tracks, invest in private coaching, or simply try to influence the school teacher to recommend the children in higher grades.
} 
skills. On the other hand, refugee immigrants differ significantly from regular migrants on these counts (see Table A1 and A2 in the Appendix; see also Haug (2005), p.270).

We use the 'Assigned Place of Residence Act' (Wohnortzuweisungsgesetz, 1989) policy to identify the effect of the existing skill composition in a neighborhood on the children of the newly arriving ethnic German immigrants. According to the 1989 policy, ethnic German immigrants were allocated to one of the 16 federal states according to pre-specified quotas. However, the policy was not binding in this form. The resettlement policy was modified in 1996 so that entrants post-1996 lost their benefits in case of non-compliance with the official assignment.

Our empirical strategy exploits this revised act to address the three identification concerns raised by Manski (2003). First, 'endogenous group membership' complicates the identification of peer effects by the tendency of individuals with shared attributes to co-reside. The revised act overcomes this by virtue of exogenous assignment of place of residence for the newly arriving ethnic German households. Second, 'correlated unobservables' raise the possibility of incorrectly attributing the influence of shared environment to the influence of peers. We compare outcomes within regions and across ethnicities to eliminate the possibility of shared correlates. Third, the 'reflection problem' makes it difficult to identify the direction of peer effects within the group. We estimate the effect of adult peers with no children on the children of Aussiedler. According to this construction, the peer group completed its education much before the children under observation ensuring that the direction of flow is indeed from the peers to the children.

Overall, we find that the average of the parental-peer-education distribution does not affect the educational outcomes of the children. However, the children benefit significantly from the presence of very high-educated parental peers, after controlling for the average education of the peer group. On the other hand, the presence of very low-educated parental peers does not adversely affect children's educational achievements. These results are robust to a range of flexible definitions of the peer group. Cunha and Heckman (2007) suggest that the impact of environment is more pronounced in disadvantaged families. We find a similar effect when we conduct the above analysis separately for different levels of parental education. We find that the primary beneficiaries of a 'good' parental peer are households located in the lower part of the education distribution. Additionally, our results hold when we restrict to adult peers, ruling out the possibility of child-tochild peer effects. Taken together, these findings lend support to our interpretation of the results as a learning effect amongst the parental generation. Further investigation reveals a set of interesting evidence. First, Aussiedler parents learn only from peers immigrating from the same country of origin and not from other immigrants. Second, the positive peer effect of the high-educated parents on low-educated parents is stronger in more polarized groups. Third, most of the positive peer 
effects seem to be driven by the effect of female parental-peers on female children.

The paper is organized as follows: Section 2 narrates the historical background of the policy. Section 3 outlines the empirical framework. Section 4 provides information on data sources and Section 5 reports the results. Section 6 concludes.

\section{Historical and Policy Background}

\subsection{Historical Background}

This study focuses on the particular group of the ethnic German immigrants to Germany. On the one hand, this group consists of individuals of German descent who lived in the pre-1945 eastern territories of the German Reich; on the other hand, it includes members of German minorities whose ancestors had already emigrated in the 18th century to Eastern Europe, mainly to Romania and the former Soviet Union. After the end of World War II and the following repartitions, about 15 million German citizens became refugees or expellees (Zimmermann, 2000). While most of them moved back to Germany in the immediate postwar period, many German citizens and ethnic Germans decided not to move or were restricted from re-settling with the post-World-War-II isolation of Eastern European countries and the construction of the Berlin Wall in 1961, which put resettlement movements practically to a standstill.

By the end of the 1980s, the fall of the Iron Curtain caused the resurgence of ethnic German migrations with immediate and massive inflows from the former Soviet Union and Warsaw Pact countries. Within five years from 1988 to 1992, more than 1.4 million ethnic Germans emigrated from these countries to Germany. In 1990 alone, some 397,000 ethnic Germans arrived (Herbert, 2001). The hierarchy of sending countries switched in the 1990s (see Figure 3). While among the earlier waves of ethnic German immigration the main source countries were Poland and Romania (only about 7 percent came from the former Soviet Union), since the mid-1990s the inflows were strongly dominated by immigrants from the former Soviet Union, mainly Kazakhstan, Kyrgyzstan, Uzbekistan, the Russian Federation and Ukraine (Haug and Sauer, 2007). ${ }^{4}$ This switch was caused by a law passed in 1993, which set the yearly quota of ethnic German immigration to 225,000 and also required immigrants from countries other than the former Soviet Union to prove they have been subject to discrimination due to their German ethnicity (Dietz, 2010; BAMF, 2013).

Figure 3 about here

\footnotetext{
${ }^{4}$ In the period 1990 to 2011 most ethnic German immigrants came from Kazakhstan (926,367), the Russian Federation (699,395), Poland (206,846), Romania (187,925), Kyrgyzstan $(73,807)$ and Ukraine $(41,198)$ (BAMF, 2013).
} 


\subsection{Institutional Setting: The "Assigned Place of Residence Act"}

Ethnic German immigration to Germany has been unique with respect to several aspects. For example, upon arrival in Germany ethnic German immigrants automatically gained German citizenship. Most importantly, however, admission to Germany has been centrally regulated. Ethnic Germans with intention to migrate to Germany had to apply for admission in their country of origin and provide proof of their German ethnicity in terms of descent and language skills. Once admission had been granted, all immigrants arrived at a central admission center in Lower Saxony, where they were registered and allocated to one of the federal states according to pre-defined quotas (the so-called Königssteiner Distribution Key). Within each federal state, they were then further allocated to specific counties based on quotas that were mainly determined by population size and economic performance of the region and also accounting for the previous numbers of allocated ethnic German immigrants.

The legal basis of this allocation process was the "Assigned Place of Residence Act" established in 1989 to avoid capacity overload and to ensure a more even, "socially acceptable" distribution across Germany. The inflow of ethnic Germans at that time represented a highly unbalanced inmigration to specific regions accelerated by chain migration and family reunification. This caused considerable housing shortages in some regions while facilities in other, more rural areas remained empty (Haug and Sauer, 2007). Yet, since the entitlement to financial and social assistance, language and training courses was not affected by an immigrant's non-compliance with the allocation assignment, the law was in practice ineffective.

In response, the Assigned Place of Residence Act was substantially modified on March 1, 1996. Ethnic German immigrants would now only be entitled to receive benefits if they complied with the allocation decision (Haug and Sauer, 2007). Exceptions were the federal states of RhinelandPalatinate and Bavaria, which chose not to implement the new law (see Table 1). Note also that Lower Saxony and Hesse adopted the law at a later point in time: Lower Saxony in April 1997 and Hesse in January 2002 (Glitz, 2012). Similarly, the East-German states of Brandenburg, SaxonyAnhalt an, Thuringa and Mecklenburg-West Pomerania adopted the law with some delay. We hence exclude Rhineland-Palatinate and Bavaria from our analysis since in these federal states, the allocation decision was not binding. For those federal states which experienced a delayed implementation of the modified law (Lower Saxony and Hesse and most East-German states), we exclude those years in which the law was not (yet) binding.

Table 1 about here

The Assigned Place of Residence Act was in effect until end-2009 without a successor legisla- 
tion implying that all regulations defined in this law have had no legislative basis since 2010. We hence restrict our analysis to ethnic Germans who immigrated to Germany in the period from 1996 to 2009 .

\subsection{Preferences and Regional Mobility}

Empirical evidence on the effectiveness of the modified Assigned Place of Residence Act since 1996 is scarce. A recent survey of ethnic German immigrants in selected communities initiated by the Federal Office for Migration and Refugees (BAMF) in 2006 gives some indicative evidence (see Haug and Sauer, 2007, p.117-118). Among survey respondents who immigrated since 1996, only 8.1 percent stated they have not been subject to the Assigned Place of Residence Act. The predominant reason indicated by this group was accommodation possibilities with relatives at arrival in Germany (39.2 percent). ${ }^{5}$

Ethnic German immigrants could state their preferences for assignment into a certain region upon arrival. However, its consideration in the allocation procedure was not guaranteed. According to the BAMF survey (see Haug and Sauer, 2007, p.84), about 54 percent of ethnic German immigrants had clear geographical preferences when coming to Germany. Among those, about 62 percent reported that their preferences had been considered in the allocation decision. These preferences were predominantly (for about 88 percent) related to relatives who live in the desired location, and only about 10 percent stated to have based their preferences on economic motives. The skill composition of the population in the destination county was not decisive of the allocation. Moreover, as Dietz (2010) points out, the admission of ethnic Germans to Germany was not related to economic factors. Importantly for our study, the skill level of the immigrants themselves did not play any role at any point in the allocation process.

To test this assumption, Table 2 provides descriptive evidence on the correlation between local ethnic German peer human capital and the (predetermined) education level of the ethnic German parents immigrating after 1996 who constitute our sample. More specifically, we examine whether the probability to reside in a district with a relatively high (above-median) share of highly educated peers is systematically related to mothers' or fathers' education levels. We find no indication of such associations, which indicates that sorting on parental education is not a concern. This lends support to our assumption that the majority of parents complied to the assigned (exogenous) placement at arrival and that regional mobility after assignment was low.

\section{Table 2 about here}

\footnotetext{
${ }^{5}$ Other reasons for exemption from the assignment law were employment offers (11.8 percent), education and apprenticeship positions (9.8 percent) and other reasons (5.9 percent).
} 
Using data from the German Socio-Economic Panel (SOEP) we find that among the ethnic German households who were subject to the modified law in 1996, only 5.14 percent moved across administrative districts within the first three years since migration. According to an earlier nationwide survey of ethnic German immigrants in 1991 and 1994, regional mobility after assignment was low even before the modified act. Only about 3.4 percent moved from the originally assigned federal state and more than 2/3 of households even stayed within the same county (Mammey, 2003, p.114). The 2006 BAMF survey confirms the finding of rather low regional mobility considering both ethnic Germans who immigrated before 1996 and those who immigrated since. 17 years after the beginning of the massive Aussiedler in-migration, over two thirds among the survey respondents still live in the very locality to which they had been assigned (see Haug and Sauer, 2007, p.88).

\section{Empirical Specification}

The main challenge in identifying the effect of the skill composition of parental peers on children's education outcomes is the presence of selection and sorting of parents across regions based

on their own ability differences. Specifically, higher educated parents would sort into regions with pre-existing high-educated individuals. In that case, we would not know whether an observed correlation between parental peer education composition and children's education is actually driven by unobserved ability or motivation. In this paper, we address the potential selection problem by exploiting the exogenous placement of ethnic German immigrants who arrived in Germany after 1996.

\subsection{Differences in Ethnic Capital Across Administrative Districts}

To get a comprehensive picture we proceed in two steps. First, we exploit the exogenous settlement of ethnic German immigrant households, which arrived in Germany after 1996, across the different regions of Germany. Since the location choice of an ethnic German household was exogenously determined by the government, the composition of the neighborhood, in which it resided at the time of entry, is likely to be independent of other choices made by the household. Specifically, we assume that parental investment decisions on the education of children is orthogonal to the region of residence of the parents in Germany. Hence, we exploit differences across regions to identify the effect of skill composition of the local peer group on the education outcomes of the children. Moreover, since the tracking system in Germany almost certainly determines adult labor market outcomes, we assume that parental investment in children to influence the level of tracking 
is crucial and captures parental aspirations. Our identification idea is captured by the following regression

$$
Y_{i c r y}=\alpha+\beta^{H} P A_{r y}^{H}+\beta^{L} P A_{r y}^{L}+\beta^{M e a n} P A_{r y}^{M e a n}+X_{i}+X_{r}+D_{c}+D_{a}+\varepsilon_{i c r y},
$$

where $Y_{\text {icry }}$ denotes the probability of being tracked into higher education of child $i$ belonging to birth cohort $c$ with year-of-immigration $y$ and located in region $r$. We assume that location ' $r$ ' is not an outcome of choice made by the ethnic German immigrant household. $P A_{r y}^{H}$ is the fraction of immigrants from ethnic German origin countries with a high educational degree in region $r$ and year $y . P A_{r y}^{L}$ is the fraction of immigrants from ethnic German origin countries with low or no educational degree in region $r$ and year $y . P A_{r y}^{\text {Mean }}$ is the mean education of immigrants from ethnic German origin countries in region $r$ and year $y$. Together, $P A_{r y}^{L}, P A_{r y}^{H}$ and $P A_{r y}^{M e a n}$ capture the composition of the local peer group. Our coefficients of interest are $\beta^{H}$, reflecting the effect of the highly educated parental peers, $\beta^{L}$, reflecting the effect of the low-educated peers, and $\beta^{\text {Mean }}$, which is the effect of the average peer quality. $X_{r} \mathrm{~s}$ are various regional level characteristics like population size of immigrants from ethnic German origin countries and mean educational level of native Germans. $X_{i}$ s are individual level controls like gender and parental education. $D_{c}$ captures cohort-of-birth fixed effects and $D_{a}$ captures age-at-migration fixed effects. Effectively, the comparison is across children with the same years of exposure to the overall German education system, but the variation arises from different peer compositions in different regions in which they are located, at the time of immigration.

\subsection{Differences in Ethnic Capital Across Ethnicities within an Administrative District}

Interpretation of the $\beta$ s as causal estimates of parental-peer-effect in equation 1 rests on the assumption that regions with a higher ethnic capital in the parental cohort are similar to regions with a lower ethnic capital in the parental cohort in every other way. However, since the parental peer group comprises of ethnic German households that entered Germany prior to 1996, they were not part of the Assigned Place of Residence Act and need not have followed a random assignment. Hence, they were likely to have sorted positively according to other characteristics of the region. For instance, high-educated individuals were likely to settle in regions with better labor markets. And these pre-existing differences across regions might confound our results in equation 1 . In other words, it is possible that the observed educational outcome of the ethnic German children is correlated with, or driven by, unobserved characteristics of the region. To address this concern we turn to within-region differences in ethnic capital across various ethnic groups. Specifically, 
we exploit differences in skill composition across different ethnicities, within the same region, that immigrated from ethnic German origin countries, to identify the effect of ethnic capital in the parental cohort on the education outcomes of the children, according to Model $2^{6},{ }^{7}$

$$
Y_{\text {icrye }}=\alpha+\beta^{H} P A_{\text {rye }}^{H}+\beta^{L} P A_{\text {rye }}^{L}+\beta^{M} P A_{\text {rye }}^{M}+X_{i}+D_{a}+D_{c}+D_{r}+D_{e}+\varepsilon_{\text {icrye }},
$$

where $Y_{\text {icrye }}$ is the probability of being tracked into higher education of individual $i$ of year-ofmigration $y$ in region $r$ and of ethnicity $e . P A_{r y e}^{H}$ is the fraction of co-ethnic parental peers with high educational degree in region $r$ and year $y . P A_{r y e}^{L}$ is the fraction of co-ethnics with low or no educational degree in region $r$ and year $y . P A_{r y e}^{M}$ is the mean education of co-ethnics in region $r$ and year $y . D_{r}$ are region fixed effects and $D_{e}$ ethnicity fixed effects. All other controls are the same as in Model 1.

\section{Data}

The Microcensus is an annual one-percent household survey representative of the resident population in Germany. The survey has been carried out annually since 1957 (since 1991 additionally in the "new" federal states including East Berlin) and provides statistical information in a detailed subject-related and regional breakdown on the demographic structure as well as on the economic and social situation of the population in terms of employment, education, housing and health. The Microcensus covers about 390,000 households including 830,000 individuals in total each year. ${ }^{8}$ In this paper, we use pooled data from the microcensus years 2007 to 2011. An important feature of the microcensus is that since 2007 it has been possible to identify ethnic German immigrants. Before then, and due to the lack of country-of-birth information, it had been difficult to distinguish ethnic German immigrants - who are automatically granted German citizenship upon immigration - from Germans born in Germany ("native Germans"). The 2007 microcensus contained for the first time information on the way individuals assumed German citizenship, whether it was by birth,

\footnotetext{
${ }^{6}$ According to this definition the peer group of an ethnic German immigrant comprises of all immigrants from the country from which he immigrated

${ }^{7}$ Since non-linear models are known to have inconsistencies in the presence of fixed effects, we report the estimates from a linear probability model. However, as a sensitivity test we also compute the marginal effects from a probit estimation. Overall, the results from the non-linear specification are similar to the ones obtained in the linear model.

${ }^{8}$ The organizational and technical preparation takes place in the Federal Statistical Office. The realization of the interviews and processing is performed by the Statistical Offices of the Federal States. The Labour Force Survey of the European Union forms an integral part of the microcensus. For more information see DESTATIS (2012).
} 
as an ethnic German immigrant, or through the usual naturalization process. ${ }^{9}$ Additionally, the microcensus 2007 introduced survey questions on previous citizenship before naturalization, which allows to identify ethnic German immigrants' countries of origin (DESTATIS, 2009).

The sample consists of children with at least one ethnic German immigrant parent, who was either born in Germany or migrated to Germany before age $12 .{ }^{10}$ Importantly, we restrict the sample of analysis to children whose parents both immigrated in or after 1996 - the year the Assigned Place of Residence Act was modified. We also specify that only those children enter our sample who are 12-22 years old in the respective year we observe them (that is, in the microcensus years 2007-2011). We chose the lower bound of age 12 because most children (96.5 percent of total, 95.6 percent of Aussiedler children) are enrolled in secondary schools by that age and we can observe the secondary schooling track they attend. The upper bound of age 22 results from the fact that by this age the majority of youths (about 75.5 percent of total, 79.3 percent of ethnic German immigrant youths) still live at home with their parents and only in this case we observe parental characteristics in our data. Parental and family information is matched to the child observation whenever a mother or a father is identified in the same household with the child. We exclude those cases in which no parental information, neither from father, nor from the mother is available. ${ }^{11}$

To capture local parental peer effects, we focus on the geographical level of NUTS-2 regions, that is, in Germany administrative districts (Regierungsbezirke) or equivalent. Germany has about 38 NUTS-2 districts, each averaging about 2 million residents. This implies that we work at the level just below German federal states. This level of aggregation is probably too large to assume personal contacts between individuals. Further analysis in this paper is hence based on the more disaggregate geographical level, the so-called Anpassungsschicht. Anpassungsschichten are regional units comprising an urban centre and the respective hinterland. There are 123 such regional units in Germany with an average population size of about 500,000 (DESTATIS, 2009).

Yet, note the trade-off in the choice of a higher level of geographic disaggregation and potential measurement error issues of the local peer variables due to small sample sizes by region

\footnotetext{
${ }^{9}$ Additionally, we define those individuals as ethnic German immigrants who immigrated from one of the typical origin countries of ethnic Germans and who assumed German citizenship within the first three years after migration.

${ }^{10}$ German-born children represent roughly 10 percent of the sample (see Table 3 ). We conducted sensitivity tests by excluding those children born in Germany from our sample. The results are similar to the ones reported using the full sample.

${ }^{11}$ We define ethnic group membership on basis of parents' citizenship, either previous citizenship before naturalization or information on second citizenship. In case of missing information or non-Aussiedler background for one parent, we rely on information from the respective other parent (32.81 percent of the sample). In case of parental pairs of two different Aussiedler countries we assign country of origin according to the child's citizenship information (1.69 percent of the sample) and, if not available, maternal information ( 0.31 percent of the sample).
} 
for ethnic Germans from specific countries of origin. In working with more disaggregated levels we might measure the relevant local peers more correctly, but also run the risk of an exacerbated measurement error in peer variables due to reduced numbers or zero peer observations in regioncountry-of-origin cells. In fact, a more aggregated analysis might be preferred in terms of sorting considerations. Our approach is generally based on the assumption that ethnic German immigrants did not move across regional areas between the year of immigration and the years we observe them (2007-2011). This assumption is all the more plausible at higher levels of aggregation. While assuming that individuals do not move across administrative districts (or Anpassungsschichten), we allow for any kind of sorting within these entities.

We study educational outcomes of ethnic German child immigrants at the secondary schooling level. The German schooling system is based on an ability tracking system which allocates children to traditionally three types of secondary schools: a lower secondary school (Hauptschule), which is designed to prepare pupils for manual professions, an intermediate secondary school (Realschule), which prepares students for administrative and lower white-collar jobs, and an upper secondary school (Gymnasium), the school type which prepares for higher education. Only the latter track allows for direct access to universities. All three types are typically public and tuitionfree. Tracking takes place after four years of primary education, when children are around 10 years old. ${ }^{12}$ The placement decision is made jointly by parents and teachers. Primary school teachers recommend a secondary school track, but these recommendations are not binding in most federal states. The early tracking decision in the German education system determines to a large extent further scholarly careers and labor market outcomes (e.g. Dustmann, 2004). While upward mobility after tracking is de jure possible, only very few pupils de facto switch tracks. One reason might be the different curricula for the respective school types that leave only little room for later upward mobility. Our outcome of interest is the probability to hold an upper secondary degree (i.e., to have graduated from Gymnasium). The early tracking system allows us to analyze also children who are too young to have graduated from secondary school, but currently attend secondary schooling. For these individuals, the outcome is defined as the probability to currently attend the upper secondary schooling track.

\subsection{Measuring Parental Peer Quality}

We define parental peers according to several dimensions - year of immigration, age, ethnicity and geographic proximity. Since parental peer quality as well as child outcomes are both measured

\footnotetext{
${ }^{12}$ Note that some variation exists in this regard as education legislation is made by the federal states. The tracking age might vary between 10 and 12 .
} 
based on information from the microcensuses 2007-2011, we want to make sure that peer quality is predetermined and has not been affected by the quality of the child immigrants themselves (hence avoiding reflection problems). We thus define for each Aussiedler child the respective parental peers as a group of individuals: a) who immigrated from the same country of origin as the child's parents, or b) of age older than 30 by the time the family immigrated. It is important to note that our definition of parental peers includes all immigrants from these origin countries, not only ethnic Germans. By choosing peers from the same country of origin, our implicit assumption is that parents associate more with immigrants from the same country of origin compared to natives and immigrants from other countries of origin, especially in the years immediately after immigration. By choosing peers older than 30, we focus specifically on a group of individuals whose education has been completed and who most likely served as a reference group for incoming immigrant parents. Furthermore, we define parental peers in a geographic dimension to capture spillover effects at the local level of governmental districts. ${ }^{13}$

We construct peer quality measures based on educational qualification according to the International Standard Classification of Education (ISCED) which uses information on the highest educational level obtained including secondary as well as vocational and tertiary degrees. ${ }^{14}$ An important scope of our analysis is to explore effects at several parts of the parental-peer-education distribution, which is why we construct several measures: First, to represent the average parental peer education we compute the mean ISCED-level of the relevant local parental peer group. Second, to represent the high end of the parental-peer-education distribution we compute the share of highly educated among the total of parental peers with highly educated being defined as those who completed academic tertiary education (i.e., ISCED-level 6). Third, we compute the share of the very low-educated parental peers, that is, the share of individuals among parental peers with at most lower secondary education and no further vocational or other post-secondary degree (i.e., ISCED-levels 1 and 2).

\footnotetext{
${ }^{13}$ To make the peer estimates meaningful, we restrict our sample to children for whom the parental peer education estimate is based on at least 10 observations. This results in varying sample sizes across various peer definitions used in Section 5.

${ }^{14}$ ISCED-levels on a 6-point scale comprise: 1 - no secondary degree, drop-out; 2 - lower secondary degree; 3 upper secondary degree; 4 - post-secondary, non-tertiary degree; 5 - short-cycle tertiary degree (typically practically oriented and occupationally specific); 6 - tertiary degree (academically based, including advanced degrees such as Ph.D.).
} 


\subsection{Description of the Sample}

Table 3 provides summary statistics of the estimation sample, which contains a total of 3,253 observations. The track attendance in Gymnasium is with 23.3 percent somewhat lower for ethnic German children in comparison to an average child in Germany. Among all students in Germany, the equivalent number ranges between 31 and 36 percent. ${ }^{15}$ There are slightly more boys than girls in the sample (53 percent). About 17 percent of the parents hold no or only a lower secondary degree ('low educated'), 62 percent have upper-secondary education and/or some post-secondary non-tertiary degree ('mid-educated'), which means that around 21 percent of parents are highly educated with some tertiary education. ${ }^{16}$

We observe a clear variation in sending countries mirroring the hierarchy of ethnic German inflow countries outlined in Section 2.1 (see also Figure 3). The two largest groups originate from Russia (41.7 percent) and Kazakhstan (35 percent). The remaining 23.3 percent have arrived from different Eastern and Southeastern European countries.

\section{Table 3 about here}

Furthermore, the descriptive statistics in Table 3 show that the observed size of local ethnic German populations in administrative districts, on which our peer calculations are based, is substantial. There is an average of 2,253 individuals from ethnic German origin countries in an administrative district. The mean education level in terms of the ISCED-classification - that is, the average parental peer education - is level 3 which corresponds to an upper secondary degree without further post-secondary education. This is only slightly lower than the average education level of about 3.2 among local native peers.

\section{Results}

\subsection{Peers Originating from any Aussiedler-Country}

Column 1 of Table 4 replicates previous studies that estimate the effect of mean peer education. Analogous to previous findings, the point estimate indicates a significant positive effect of the mean parental peer-education on the education of children brought up in the same neighborhood.

\footnotetext{
${ }^{15}$ In 2005/06 (2011/12), about 31 (36) percent of all students in Germany attend Gymnasium in 8th grade (Federal Statistical Office, 2006 and 2012, Fachserie 11.1).

${ }^{16}$ Parents' education level is defined as 'low' if both father and mother hold no or only a lower secondary degree. We define parents to be 'highly' educated if at least one of the parents hold some tertiary degree. The remaining are defined as 'mid-educated'.
} 
Next we proceed towards specifications that allow for compositional differences in the education level of the neighborhood.

Column 2 provides the results obtained from estimating Model 1. The point estimates suggest that having more parental peers from the top of the education distribution improves educational achievement of children, while growing up in an environment with more parental peers from the bottom of the education distribution harms the educational achievement of children. Specifically, a one-percent increase in the fraction of very high-educated parental peers leads to 1.7 percentage point higher probability for the child being tracked to an upper secondary school. On the other hand, a one-percent increase in the fraction of very low-educated parental peers reduces the probability of being tracked to an upper secondary school by 0.44 percentage points. However, the negative effect of the low-educated peers is statistically insignificant suggesting that the bottom of the peer education distribution does not affect the education outcomes of the children. In addition, we find that the average peer education does not have any significant impact on the educational outcomes of the children after controlling for the top and the bottom of the peer-education distribution.

\subsection{Learning Effect: Who is Most Affected by the Environment?}

Previous literature finds considerable heterogeneity in peer effects within the classroom. In addition, Cunha and Heckman (2007) suggests large benefits of good environment accruing to people from disadvantaged families. In what follows, we analyze whether the different parts of the peer education distribution have differential effects on children coming from different backgrounds. Particularly, if the positive effect of the higher educated peers reflects a learning process by parents then we expect the relatively lower educated parents to gain more from a good quality environment compared to the high-educated parents. Hence we estimate Model 1 separately for children of low, middle and highly educated parents. Results are reported in Columns 3-5 of Table 4. The positive effect of very high-educated parental peers is seen across all groups, although for the low-educated parents the benefit is much higher compared to the high and middle educated parents. Moreover, high-educated peers do not seem to significantly affect the children of middle and highly educated parents. For children whose parents are very low-educated, a one-percentage point increase in the fraction of very high-educated parental peers leads to 3.5 percentage point higher probability of being tracked to an upper secondary school compared to a magnitude of only 1.7 percentage points for the full sample. On the other hand, the adverse effect of the very low-educated peers is not significantly different from zero for the full sample as well as across all three sub-samples.

Table 4 about here 


\subsection{Peers Originating from Same Country of Origin}

As discussed above, the random placement of ethnic German immigrants, who arrived in Germany after 1996, effectively addresses the possibility that higher educated parents are sorting into higher educated neighborhoods. To the extent that peer quality of a region is the only feature affecting children's education outcomes, the above specifications estimate the causal effect of peer quality on children's education. However, this might not be a reasonable assumption, particularly because the ethnic German immigrants who comprise the peer group were not part of a random assignment policy. Hence, it remains possible that higher educated parental peers sorted in to regions with greater labor market opportunities when they moved to Germany. This in turn implies that unobserved regional characteristics might be correlated with parental investment decisions on children's education in that region. To address this problem, we estimate within-region specifications by exploiting variations in educational attainment across different ethnic peer groups within a region. These specifications, as described in Model 2, allow for causal interpretation of the peer effects. The results are reported in Table 5.

For the full sample, the results are reported in Column 1. The coefficients indicate that no segment of the peer education distribution - high, low or mean - has any impact on children's education outcomes. The estimates are all close to zero and insignificant. Columns $2-4$ report the results from the separate sub-samples. The very high-educated parental peers have a significant positive effect on the children of low-educated parents but no beneficial impact on the children of middle or highly educated parents. A Chi-Square test rejects the equality of the coefficients (effect of high-educated peers) between low and middle-educated parents and between low and higheducated parents. On the other hand, it fails to reject equality between middle and highly educated parents. The estimates indicate that a one-percentage point increase in the fraction of very higheducated parental peers leads to a 2.4 percentage point higher probability of being tracked to an upper secondary school. At the average this implies that for a one-percent increase in the share of the highly educated in the peer group, the probability of going to Gymnasium increases by, approximately, 1.9 percent for the children of the low-educated parents. ${ }^{17}$ On the lower tail of the peer-education distribution, a one-percentage point increase in the fraction of very low-educated peers leads to approximately a 1-percentage point lower probability of being tracked to an upper secondary school, although this negative influence is not significantly different from zero. Overall, the children of the low, mid and highly educated parents remain unaffected by the low-educated

\footnotetext{
${ }^{17}$ The mean probability of being tracked in Gymnasium is 0.15 and the mean share of high-educated co-ethnic peers is 0.12 for the regression sample.
} 
peers.

\section{Table 5 about here}

\subsection{Robustness}

Since the construction of the peer-group is subjective, our results could be driven by the way we define the parental peers. Below we conduct a set of sensitivity checks to see if our estimates are robust to alternate peer definitions.

\subsubsection{Size of the Peer Group}

One of the main inputs in our empirical specification is the peer-education variable. Since a peergroup cell, in Model 2, is defined by the intersection of region, ethnicity and year of immigration, some cells are likely to be thinly populated, making the estimates less precise. Hence, in Table 6 we restrict our estimation to only those children for whom the parental-peer-education measure is based on at least 50 observations. This reduces our overall sample size from 3,253 to 2,935. The magnitude of the effect of high-educated peers is the same as in our main specification, although the estimates are less precise now. ${ }^{18}$

\section{Table 6 about here}

\subsubsection{Alternate Definitions of Geographic Neighborhood}

Our construction of the peer measure rests on the assumption that an administrative district (Regierungsbezirk) forms the relevant geographic area within which individuals interact the most. Given the subjectivity involved in defining a geographic neighborhood, we conduct sensitivity tests using peer measures at a geographic unit smaller than the administrative district - the Anpassungsschicht (see Section 4.1). The results from this analysis are reported in Table 7. They indicate, as before, a positive effect of the high-educated peers and no effect coming from either the average peer education or the lower part of the peer education distribution. Once again, the effects are all concentrated on the lowest educated parental sample with no influence on more educated parents.

\section{Table 7 about here}

\footnotetext{
${ }^{18}$ We additionally restricted our sample to individuals for whom the peer-education measure is based on at least 15, 75 and 100 observations with similar results, but insignificant when restricting to at least 100 observations.
} 


\subsubsection{Who Are the Most Influential Peers?}

In our construction of the peer variable, in Model 2 we implicitly assume that the Aussiedler parents learn only from other individuals in their geographic-neighborhood with the same country of origin. In Table 4 we show that, indeed, the average education of the native Germans does not affect the education outcomes of the Aussiedler children. In Table 5, these effects are included as part of the administrative district fixed effect. However, it could still be the case that immigrants as a group learn from each other irrespective of their specific ethnicities. In fact, the results in Table 4 imply a combined peer effect coming from high-educated individuals of any Aussiedler country-of-origin. To understand who the most influential peers are, we estimate a more flexible specification. We regroup the peers according to whether they come from the same country as the respective family (i.e. child) or from a different Aussiedler origin country and estimate the following equation:

$$
\begin{aligned}
& Y_{\text {icrye }}=\alpha+\beta_{e}^{H} P A_{\text {rye }}^{H}+\beta_{e}^{L} P A_{\text {rye }}^{L}+\beta_{e}^{\text {Mean }} P A_{\text {rye }}^{\text {Mean }} \\
& \beta_{(-e)}^{H} P A_{r y(-e)}^{H}+\beta_{(-e)}^{L} P A_{r y(-e)}^{L}+\beta_{(-e)}^{\text {Mean }} P A_{r y(-e)}^{\text {Mean }} \\
& +X_{i}+D_{a}+D_{c}+D_{r}+D_{e}+\varepsilon_{\text {icrye }},
\end{aligned}
$$

where $Y_{\text {icrye }}$ is the probability of being tracked into higher education of individual $i$ of year of migration $y$ in region $r$ and of ethnicity e. $P A_{r y e}^{H}$ is the fraction of parental peers with a high educational degree in region $r$, year $y$ and the same country-of-origin as the parents, $e . P A_{r y e}^{L}$ is, analogously, the fraction of peers of own-ethnicity with low or no educational degree and $P A_{\text {rye }}^{\text {Mean }}$ is the mean education of the peer-group. Additionally, we now include $P A_{r y(-e)}^{H}$ and $P A_{r y(-e)}^{L}$ which are the fractions of high and low-educated potential-peers in region $r$, year $y$ but are not of the same ethnic origin as the parents, $e$. All other controls are same as in Model 2.

Results from this estimation are reported in Table 8. As before, the high-educated peers of same ethnicity as the parents have a strong positive influence on the educational outcomes of the Aussiedler children. The magnitude of the effect is almost identical to the ones reported in Table 5. On the other hand, the potential parental-peers residing in the same region but belonging to other ethnicities do not have any significant influence on the Aussiedler children.

While this is an interesting finding in its own right, it also lends support to our assumption (and much of the previous immigrant literature) that the most relevant peers for immigrants are people belonging to the same country of origin. 


\section{Table 8 about here}

\subsection{Reflection Problem: Parental Learning Effect}

Overall, our results suggest a consistent pattern of peer effects. Children of lowest educated parents gain the most from a good parental peer. The relatively higher educated parents do not seem to benefit from a good peer. We interpret this evidence of positive peer effects as a parental learning experience. However, we cannot be certain whether the learning effect reflects parental aspirations or whether it is a direct positive influence of the child peers on the newly arrived child Aussiedlers. In other words, regions that have a high share of high-educated Aussiedler peers would also have a high share of highly motivated children of these peers. It could be that the peer effect we estimate is flowing directly from these highly motivated child-peers to the children under study.

In addition, the possibility of reflection problem clouds our interpretation further if the peereffect is flowing from the child-peers. Suppose it is indeed the case that the Aussiedler children who immigrated after 1996 are learning from the motivated and ambitious child peers of the higheducated parents. If so, it is also possible that the child who moved after 1996 is highly motivated to begin with and it is the child peers who are positively influenced by the former. Then we cannot identify the direction of the peer effect. On the other hand, if the effect is flowing from adult peers, who have already completed their education, it is only possible that the education-peer-effect is flowing in the direction of the Aussiedler children who immigrated after 1996. Moreover, given the very young age of the children, it is likely to be a parental learning effect passed on to their children. To disentangle these possibilities, we construct our peer group based only on adults from Aussiedler ethnicities with no children. The results are reported in Table 9.

\section{Table 9 about here}

The influence of the adult peers on Aussiedler children track our main results. The positive effect of very high-educated adult peers is only observed for children of the low-educated parents. For children whose parents are very low-educated, a one-percent increase in the fraction of very high-educated adult peers leads to a 1.2 percent higher probability of being tracked to an upper secondary school at the sample average. ${ }^{19}$ As in our main regressions, the effect of high-educated peers is insignificant for the sample of middle and high-educated parents. This lends support to our interpretation of the results as a learning effect amongst the parental generation. Moreover, it

\footnotetext{
${ }^{19}$ The mean probability of being tracked in Gymnasium is 0.15 and the mean share of high-educated co-ethnic peers is 0.12 for the regression sample.
} 
also indicates that the direction of the effect is from the existing adult peers to the newly arrived child Aussiedlers.

\subsection{Polarization}

Overall, our results suggest that peer-education heterogeneity has a beneficial effect on the children of low-educated parents. Our findings of non-linear peer effects are consistent with the previous literature on classroom peer effects (Duflo et al., 2011; Lyle, 2009; Carrell et al., 2013). From a policy perspective it implies that children in the lower part of the parental-education distribution would gain more in a polarized group - i.e. if middle educated peers are replaced by high-educated peers. However, quite on the contrary, Carrell et al. (2013) find that low ability students are negatively affected by high ability peers in completely polarized groups with no middle ability category. They argue that low and high ability students do not interact in polarized groups. These findings have particular relevance in the context of immigrant peer effects. If some ethnicities have immigrants only from the very low and very high ends of the education distribution (in the case of guest workers for instance), then the low-skilled immigrants are less likely to overcome intergenerational persistence.

While we cannot find clearly bimodal groups in our data, we construct various measures of polarization to test whether the magnitude of peer effect varies across these samples. In Table 10 we report the results from this analysis. We restrict our attention to the sample of low-educated parents here. Column 1 restricts to groups in which more than 80 percent of the peers are either high or low-educated. The results are consistent with our primary findings: Children of low-educated parents benefit significantly from high-educated parental peers. Column 2 restricts to groups with more than 40 percent of low-educated parents but no restriction on the remaining distribution of middle and high-educated. In this case, the size of the positive effect is also comparable to our main findings but the coefficient is imprecisely estimated. In Column 3 we construct a measure of polarization and restrict to cases with high levels of polarization. ${ }^{20}$ Once again, the results reflect our baseline findings. However, in all three samples, reflecting various definitions of polarization, the magnitude of the effect of high-educated peers on children of low-educated parents is higher than our baseline findings in Table 5 (the magnitudes range from 2.3 to 2.6 percent). This suggests that learning effects might be stronger in more polarized environments for immigrants.

\section{Table 10 about here}

\footnotetext{
${ }^{20}$ We follow Montalvo and Reynal-Querol $(2005,2008)$ to construct the index of discrete polarization. Higher than median values of this index indicate a high level of polarization.
} 


\subsection{Gender}

Finally, we turn to the question of gender heterogeneity in peer effects. There are two related issues: a) whether there is any difference in parental-peer influence for boys versus girls, and b) who do parents learn from when the child is male and who are the relevant peers for a female child.

Table 11 shows the results from four separate regressions. Once again, we focus only on the low-educated parental sample. Columns 1 and 2 estimate the influence coming from male peers on male and female children respectively. Male peers do not seem to exert any significant influence on children's educational outcomes. On the other hand, high educated female peers have a positive effect on both boys and girls although the effect is insignificant on boys. Our findings on gender heterogeneity are, in part, similar to Lavy et al. (2012). They also find a strong positive influence of the high-educated peers on girls but a relatively weaker effect on boys. ${ }^{21}$

Table 11 about here

\section{Conclusion}

In this paper we estimate the effect of parental peer quality on educational attainment of children using the 'Assigned Place of Residence Act' in Germany. According to the Act, ethnic Germans were assigned a place of residence by the German government. After a substantial modification of the law in 1996, adherence to the assignment was ensured by ineligibility to welfare programs of households who failed to follow the central assignment. This de-facto exogenous assignment, as per the 1996 version of the Act, helps us to address sorting biases in the estimation of peer effects that originate from endogenous location choice. In addition, we estimate the effect of purely adult peers whose completed education levels are unlikely to be affected by the children under study, eliminating possibilities of a reflection problem. Moreover, this policy allows us to study immigrant groups which are more likely to be generalized as regular labor migrants, rather than refugee migrants, who have been subject of previous studies exploiting settlement policies.

We find that the educational attainment of children is not affected by the average educational attainment of the peer group. Our findings imply that it is important to look beyond the average. There is a significant positive effect coming from the probability mass in the upper end of the peer distribution. Children have a higher probability of attending upper secondary school when parents

\footnotetext{
${ }^{21}$ However, our approach is distinct from Lavy et al. (2012) in our construction of gender-specific peer groups. We also estimated the effect of the overall peer group separately on girls and boys. These results are more directly comparable to Lavy et al. (2012). Also here our estimates suggest a strong positive influence of high-educated peers on girls but no comparable effect on boys. The presence of low-educated peers continue to be insignificant.
} 
are exogenously placed in neighborhoods with a high fraction of very high-educated ethnic peers. In contrast, we do not find any negative influence of the low-educated peers. In addition, we find that the low-educated parents benefit most from being exposed to a high-educated peer group while the mid or high educated parents do not seem to benefit from the presence of high-educated neighbors. Our estimates suggest that among low-educated parents a one-percent higher fraction of high-educated adults in the peer group leads to a 1.9 percent higher probability of their children opting for the highest education track in Germany. Our results are robust to a range of alternate definitions of the relevant peer group and larger in more polarized groups. Further investigation reveals that the positive peer effect is restricted to female children and is driven by the educational outcome of female parental peers. No significant effects are observed for male children.

Another interesting finding is in terms of the relevant peer group. While most of the literature on ethnic capital assumes that people of one's own ethnicity are the ones relevant for socioeconomic outcomes of the immigrants, there is to date no empirical evidence on the validity of this assumption. On the other hand, past evidence finds a positive correlation between native peer quality and immigrant outcomes. We directly test for this possibility - whether it is mainly the peers sharing the same ethnicity who affect the outcomes of immigrants or whether the peer effect flows from any immigrant in the neighborhood. Our findings support the assumption that immigrants predominantly learn from the people of same ethnicity.

Exogenous allocation policies have been widely practiced in school settings to produce desired educational outcomes among children (Carrell et al., 2013). However, in the debate around assimilation and integration of immigrants, these kinds of policies are rarely practiced. Our findings suggest that policies which prevent endogenous sorting are likely to benefit the low-ability immigrants significantly in terms of intergenerational mobility, with no significant adverse effects on the high-ability immigrants. 


\section{References}

Angrist, J. D. and K. Lang (2004). Does School Integration Generate Peer Effects? Evidence from Boston's Metco Program. American Economic Review 94(5), 1613-1634.

Åslund, O., P.-A. Edin, P. Fredriksson, and H. Grönquist (2011). Peers, Neighborhoods, and Immigrant Student Achievement: Evidence from a Placement Policy. American Economic Journal: Applied Economics 3(2), 67-95.

Åslund, O. and P. Fredriksson (2009). Peer Effects in Welfare Dependence - Quasi-Experimental Evidence. Journal of Human Resources 44(3), 798-825.

BAMF (2013). Migrationsbericht 2011. Technical report, Bundesamt für Migration und Flüchtlinge (BAMF), Nürnberg, available at http://www.bamf.de/SharedDocs/Anlagen/DE/Publikationen/ Migrationsberichte/migrationsbericht-2011.html.

Bertrand, M., E. F. Luttmer, and S. Mullainathan (2000). Network Effects and Welfare Cultures. Quarterly Journal of Economics 115(3), 1019-1055.

Black, S. E., P. J. Devereux, and K. G. Salvanes (2005). Why the Apple Doesn't Fall Far: Understanding Intergenerational Transmission of Human Capital. American Economic Review 95(1), 437-442.

Borjas, G. J. (1992). Ethnic Capital and Intergenerational Mobility. Quarterly Journal of Economics 107(1), 123-150.

Borjas, G. J. (1995). Ethnicity, Neighborhoods, and Human-Capital Externalities. American Economic Review 85(3), 365-390.

Card, D. and J. Rothstein (2007). Racial Segregation and the Black-White Test Score Gap. Journal of Public Economics 91(11), 2158-2184.

Carrell, S. E., B. I. Sacerdote, and J. E. West (2013). From Natural Variation to Optimal Policy? The Importance of Endogenous Peer Group Formation. Econometrica 81(3), 855-882.

Cortes, K. E. (2006). The Effects of Age at Arrival and Enclave Schools on the Academic Performance of Immigrant Children. Economics of Education Review 25(2), 121-132.

Crul, M. and H. Vermeulen (2003). The Second Generation in Europe. International Migration Review 37(4), 965-986.

Cunha, F. and J. Heckman (2007). The Technology of Skill Formation. American Economic Review 97(2), $31-47$.

Cutler, D. M. and E. L. Glaeser (1997). Are Ghettos Good or Bad? Quarterly Journal of Economics 112(3), $827-872$.

DESTATIS (2009). Qualitätsbericht Mikrozensus 2007 - Bevölkerung mit Migrationshintergrund. Technical report, Federal Statistical Office (DESTATIS), Wiesbaden, available at https://www.destatis.de/DE/Publikationen/Qualitaetsberichte/Bevoelkerung/ MigrationshintergrundMikrozensus2007.pdf. 
DESTATIS (2012). Qualitätsbericht Mikrozensus 2011. Technical report, Federal Statistical Office (DESTATIS), Wiesbaden, available at https://www.destatis.de/DE/Publikationen/ Qualitaetsberichte/Bevoelkerung/Mikrozensus2011.pdf.

Dietz, B. (2010). German and Jewish Migration from the Former Soviet Union to Germany: Background, Trends and Implications. Journal of Ethnic and Migration Studies 24(4), 635-652.

Duflo, E., P. Dupas, and M. Kremer (2011). Peer Effects, Teacher Incentives, and the Impact of Tracking: Evidence from a Randomized Evaluation in Kenya. American Economic Review 101(5), 1739-1774.

Dustmann, C. (2004). Parental Background, Secondary School Track Choice, and Wages. Oxford Economic Papers 56(2), 209-230.

Finnie, R. and R. Mueller (2009). Access to Post-Secondary Education In Canada Among The Children of Canadian Immigrants. MESA Project Research Paper 2009-1, Educational Policy Institute, Toronto, ON. Available at http://dx.doi.org/10.2139/ssrn.2256037.

Giustinelli, P. (2010). Uncertain Outcomes and Child-Parent Decision Making in Curriculum Choice: What Data Do We Need to Tell them Apart? Unpublished manuscript, Survey Research Center, University of Michigan.

Glitz, A. (2012). The Labor Market Impact of Immigration: A Quasi-Experiment Exploiting Immigrant Location Rules in Germany. Journal of Labor Economics 30(1), 175-213.

Hammarstedt, M. and M. Palme (2006). Intergenerational Mobility, Human Capital Transmission and the Earnings of Second-Generation Immigrants in Sweden. IZA Discussion Paper 1943, Institute for the Study of Labor (IZA), Bonn.

Hanushek, E. A., J. F. Kain, and S. G. Rivkin (2009). New Evidence about Brown v. Board of Education: The Complex Effects of School Racial Composition on Achievement. Journal of Labor Economics 27(3), 349-383.

Haug, S. (2005). Zum Verlauf des Zweitspracherwerbs im Migrationskontext. Zeitschrift für Erziehungswissenschaft 8(2), 263-284.

Haug, S. and L. Sauer (2007). Zuwanderung und Integration von (Spät-)Aussiedlern - Ermittlung und Bewertung der Auswirkungen des Wohnortzuweisungsgesetzes. Technical report, Bundesamt für Migration und Flüchtlinge (BAMF), Nürnberg. Available at http://www.bamf.de/SharedDocs/Anlagen/ DE/Publikationen/Forschungsberichte/fb03-wohnortzuweisungsgesetz.html.

Herbert, U. (2001). Geschichte der Ausländerpolitik in Deutschland - Saisonarbeiter, Zwangsarbeiter, Gastarbeiter, Flüchtlinge. Munich: C.H. Beck.

Lavy, V., O. Silva, and F. Weinhardt (2012). The Good, the Bad, and the Average: Evidence on Ability Peer Effects in Schools. Journal of Labor Economics 30(2), 367-414.

Leon, A. (2005). Does 'Ethnic Capital' Matter? Identifying Peer Effects in the Intergenerational Transmission of Ethnic Differentials. Unpublished manuscript, University of Pittsburgh. 
Lyle, D. S. (2009). The Effects of Peer Group Heterogeneity on the Production of Human Capital at West Point. American Economic Journal: Applied Economics 1(4), 69-84.

Mammey, U. (2003). Segregation, regionale Mobilität und soziale Integration von Aussiedlern. In K. Bade and J. Oltmer (Eds.), Aussiedler: Deutsche Einwanderer aus Osteuropa, IMIS-Schrifen, Band 8, pp. 107-126. Göttingen.

Manski, C. F. (2003). Identification Problems in the Social Sciences and Everyday Life. Southern Economic Journal 70(1), 11-21.

Montalvo, J. G. and M. Reynal-Querol (2005). Ethnic Polarization, Potential Conflict and Civil Wars. American Economic Review 95(3), 796-816.

Montalvo, J. G. and M. Reynal-Querol (2008). Discrete Polarisation with an Application to the Determinants of Genocides. The Economic Journal 118(533), 1835-1865.

Nielsen, H., M. Rosholm, N. Smith, and L. Husted (2003). The School-to-work Transiton of 2nd Generation Immigrants in Denmark. Journal of Population Economics 16(296), 755-786.

Österberg, T. (2000). Economic Perspectives on Immigrants and Intergenerational Transmissions. Göteborg University.

Van Ours, J. C. and J. Veenman (2004). From Parent to Child: Early Labor Market Experiences of SecondGeneration Immigrants in the Netherlands. De Economist 152(4), 473-490.

Zimmermann, K. F. (2000). Aussiedler seit 1989 - Bilanz und Perspektiven (Ethnic German Migrants Since 1989 - Evaluation and Perspectives). Jahrbuch für Wirtschaftsgeschichte 2000/1, 225-237. 
Figure 1: Compositional Differences in Peers - A

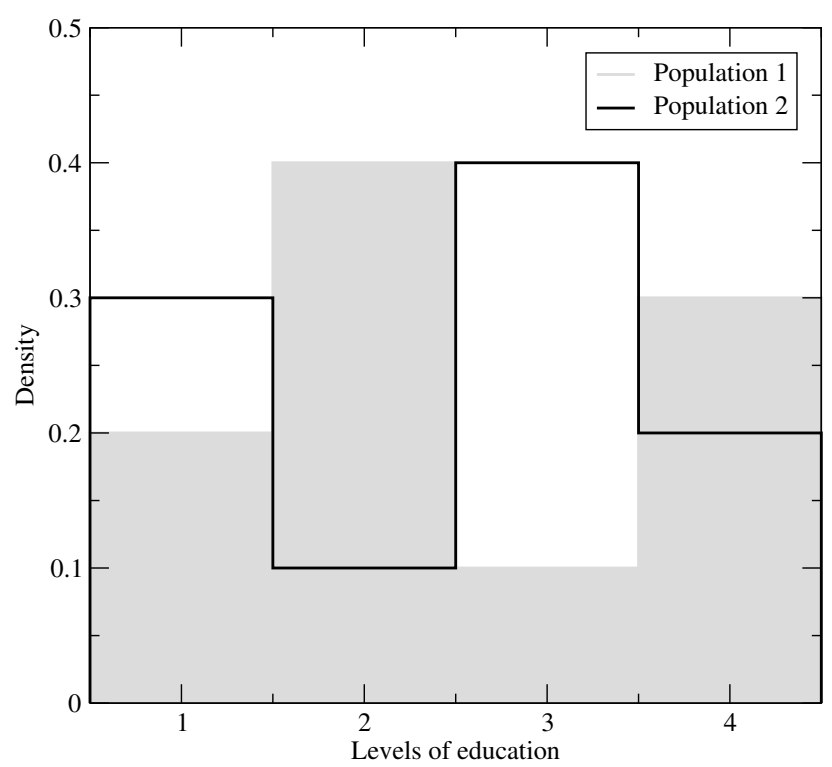

Notes: Population-1 and Population-2 have the same mean but Population-1 has a higher probability mass on the right tail than Population-2.

Figure 2: Compositional Differences in Peers - A

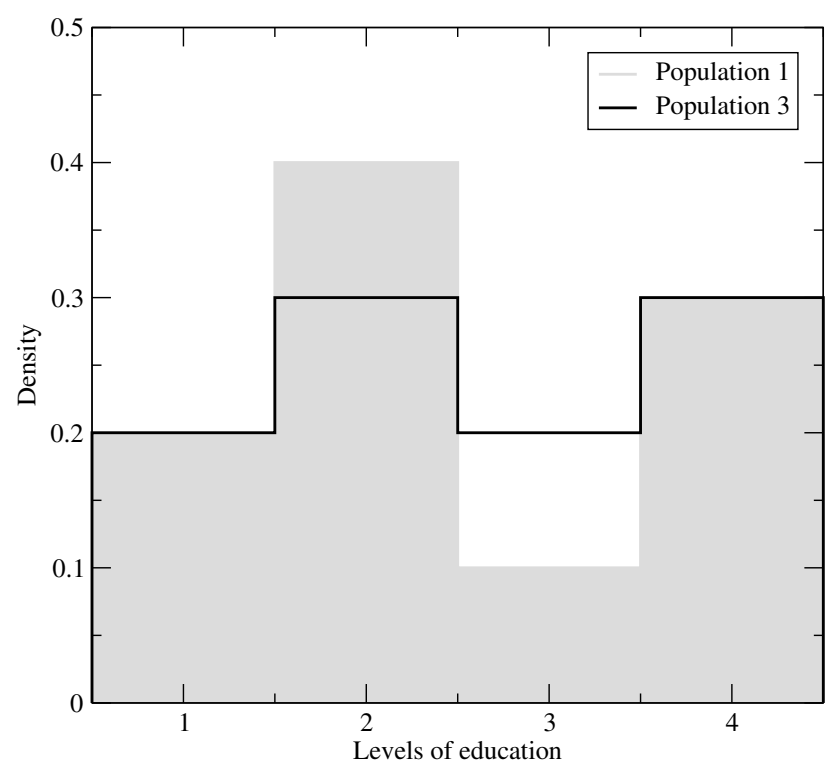

Notes: Population-3 has a higher mean than Population-1 but has the same probability mass as Population-1 in the higher tail. 
Figure 3: Immigration of Ethnic Germans to Germany by Source Country (1950-2010)

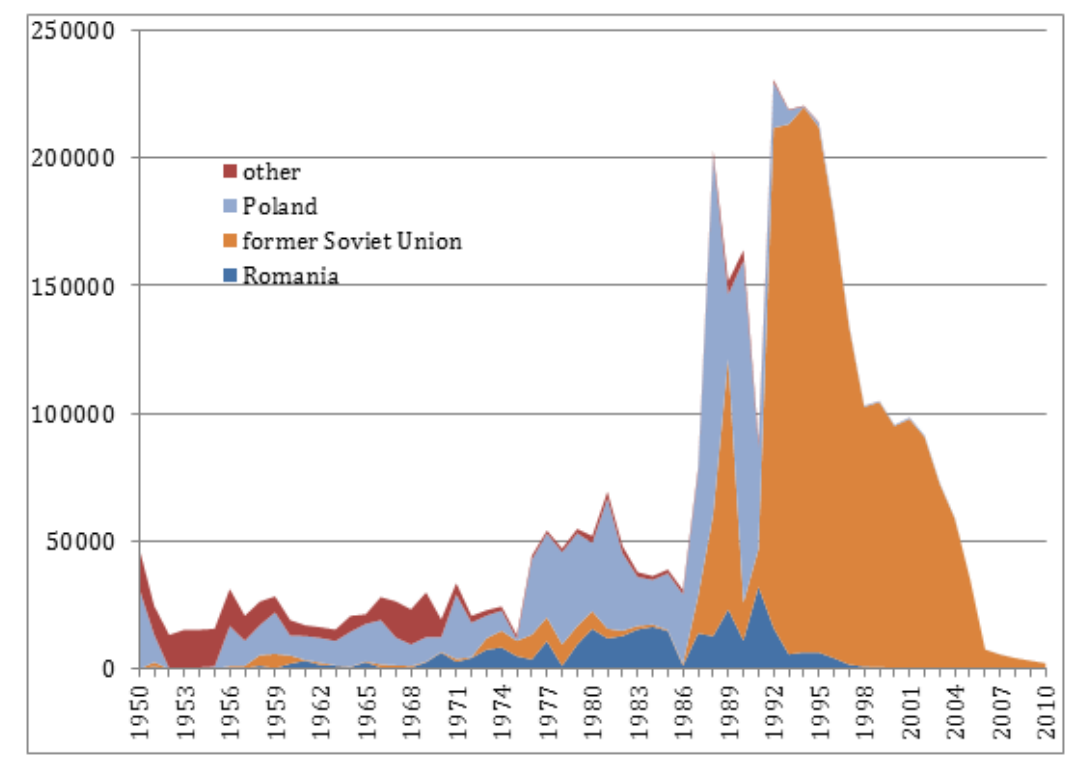

Source: Federal Administration Office, BAMF 2013. 
Table 1: German Federal States and their Implementation of the Modified "Assigned Place of Residence Act"

\begin{tabular}{lrrrrr}
\hline Federal State & $\begin{array}{r}\text { Nr. of } \\
\text { Districts }\end{array}$ & $\begin{array}{r}\text { State } \\
\text { Quota }(\%)\end{array}$ & $\begin{array}{r}\text { Law } \\
\text { Implemented }\end{array}$ & $\begin{array}{r}\text { Date of } \\
\text { Implementation }\end{array}$ & $\begin{array}{r}\text { In } \\
\text { Sample }\end{array}$ \\
\hline North Rhine-Westphalia & 5 & 21.59 & yes & $1 / 3 / 1996$ & yes \\
Bavaria & 7 & 14.90 & no & - & no \\
Baden-Württemberg & 4 & 12.80 & yes & $1 / 3 / 1996$ & yes \\
Lower Saxony & 4 & 9.17 & yes & $7 / 3 / 1997$ & yes, from 1997 \\
Hesse & 3 & 7.31 & yes & $1 / 1 / 2002$ & yes, from 2002 \\
Saxony & 1 & 5.28 & yes & $1 / 3 / 1996$ & yes \\
Berlin & 1 & 4.95 & yes & $1 / 3 / 1996$ & yes \\
Rhineland-Palatinate & 3 & 4.70 & no & $-1 / 3 / 1996$ & no \\
Schleswig-Holstein & 1 & 3.34 & yes & yes \\
Brandenburg & 1 & 3.12 & yes & $17 / 12 / 1996$ & yes, from 1997 \\
Saxony-Anhalt & 3 & 3.08 & yes & $21 / 1 / 1998$ & yes, from 1998 \\
Thuringa & 1 & 2.90 & yes & $15 / 7 / 1998$ & yes, from 1998 \\
Mecklenburg-West Pomerania & 1 & 2.13 & yes & $1 / 1 / 2002$ & yes, from 2002 \\
Hamburg & 1 & 2.52 & yes & $1 / 3 / 1996$ & yes \\
Saarland & 1 & 1.24 & yes & $11 / 3 / 1996$ & yes \\
Bremen & 1 & 0.90 & yes & $1 / 3 / 1996$ & yes \\
\hline
\end{tabular}

Source: Haug and Sauer, 2007; Glitz, 2012. 
Table 2: Correlation between Local Ethnic German Peer Education and Parental Human Capital

\begin{tabular}{|c|c|}
\hline Dependent variable: Above-medi & ed local peers in district \\
\hline Mother education (ref.: ISCED 1) & \\
\hline ISCED 2 & $\begin{array}{c}0.015 \\
(0.065)\end{array}$ \\
\hline ISCED 3 & $\begin{array}{c}0.043 \\
(0.064)\end{array}$ \\
\hline ISCED 4 & $\begin{array}{l}-0.023 \\
(0.079)\end{array}$ \\
\hline ISCED 5 & $\begin{array}{c}0.054 \\
(0.072)\end{array}$ \\
\hline ISCED 6 & $\begin{array}{c}0.052 \\
(0.069)\end{array}$ \\
\hline Father education (ref.: ISCED 1) & \\
\hline ISCED 2 & $\begin{array}{c}-0.058 \\
(0.067)\end{array}$ \\
\hline ISCED 3 & $\begin{array}{c}0.011 \\
(0.066)\end{array}$ \\
\hline ISCED 4 & $\begin{array}{c}-0.010 \\
(0.086)\end{array}$ \\
\hline ISCED 5 & $\begin{array}{c}0.011 \\
(0.077)\end{array}$ \\
\hline ISCED 6 & $\begin{array}{c}0.097 \\
(0.073)\end{array}$ \\
\hline$N$ & 2,554 \\
\hline $\begin{array}{l}\text { Source: Research Data Centres of the } \mathrm{Fe} \\
\text { Länder, Microcensus (2007-2011), own } \\
\text { Notes: Probability of a household resic } \\
\text { function of mothers' education and fat } \\
\text { effects, ethnicity fixed effects, age at } \mathrm{m} \\
\text { household size. Sample consists of Aus } \\
\text { Place of Residence Act" according to } \\
\text { and of age } 12-22 \text { when observed in mi } \\
\text { The unit of interest here is the househol } \\
\text { (child). ISCED-levels: (1) no seconda } \\
\text { upper secondary degree; (4) post-second } \\
\text { (6) tertiary degree. }\end{array}$ & $\begin{array}{l}\text { e and the Statistical Offices of the } \\
\text { ed vs. low-educated district as a } \\
\text { controlling for survey year fixed } \\
\text { immigration year dummies and } \\
\text { fected by the modified "Assigned } \\
\text { one child aged } 0-12 \text { at migration } \\
\text { (see Section } 4 \text { for more details). } \\
\text { wing analysis it is the individual } \\
\text { (2) lower secondary degree; (3) } \\
\text { ee; (5) short-cycle tertiary degree; }\end{array}$ \\
\hline
\end{tabular}


Table 3: Summary Statistics of Selected Sample Characteristics

\begin{tabular}{lcc}
\hline & Mean & Std. Dev. \\
\cline { 2 - 3 } Tracking probability into Gymnasium & 0.233 & 0.423 \\
Male & 0.526 & 0.499 \\
Age at migration & 6.457 & 3.717 \\
German-born & 0.103 & 0.304 \\
Parents low educated & 0.166 & 0.372 \\
Parents mid educated & 0.622 & 0.485 \\
Mean education among local ethnic German peers & 3.034 & 0.191 \\
Mean education among local native peers & 3.218 & 0.112 \\
Population size of local ethnic German peers & 2,253 & 1,338 \\
Share high educated among local ethnic German peers & 0.128 & 0.048 \\
Share low educated among local ethnic German peers & 0.324 & 0.057 \\
Population size of local co-ethnic peers & 321 & 311 \\
Share high educated among local co-ethnic peers & 0.141 & 0.094 \\
Share low educated among local co-ethnic peers & 0.354 & 0.105 \\
Population size of local co-ethnic peers w/o children age $0-16$ & 193 & 198 \\
Share high educated among local co-ethnic peers w/o children age $0-16$ & 0.142 & 0.105 \\
Share low educated among local co-ethnic peers w/o children age $0-16$ & 0.419 & 0.120 \\
CIS-Russian Federation & 0.417 & 0.493 \\
CIS-Kazakhstan & 0.350 & 0.477 \\
CIS-Other & 0.093 & 0.291 \\
Poland & 0.076 & 0.264 \\
Ukraine & 0.035 & 0.185 \\
Hungary & 0.015 & 0.121 \\
Former Yugoslavia & 0.008 & 0.087 \\
Romania & 0.005 & 0.072 \\
\hline$N$ & 3,253 & \\
\hline
\end{tabular}

Source: Research Data Centres of the Federal Statistical Office and the Statistical Offices of the Länder, Microcensus (2007-2011), own calculations.

Notes: Apart from the Russian Federation and Kazakhstan, other official member states of the Commonwealth of Independent States (CIS) are Armenia, Azerbaijan, Belarus, Kyrgyzstan, Moldova, Tajikistan, and Uzbekistan. Parents' education level is defined as 'low' if both father and mother hold no or only a lower secondary degree. We define parents to be 'highly' educated if at least one of the parents hold some tertiary degree. The remaining are defined as 'mid-educated'. Mean peer education is computed as the mean ISCED-level of the relevant peer group. 'Highly' educated peers are those who completed academic tertiary education (i.e., ISCED-level 6), while 'low' educated peers are those with at most lower secondary education and no further vocational or other post-secondary degree (i.e., ISCED-levels 1 and 2). Age at migration is set to zero for those children born in Germany. 
Table 4: Parental Peer Definition: Peers Originating from any Aussiedler Country

Dependent variable: Tracking probability into upper secondary school

\begin{tabular}{lccccc}
\hline & & & \multicolumn{3}{c}{ Split-Samples by Parental Education } \\
\cline { 5 - 6 } & $\begin{array}{c}\text { Full } \\
(1)\end{array}$ & $\begin{array}{c}\text { Full } \\
(2)\end{array}$ & $\begin{array}{c}\text { Low } \\
(3)\end{array}$ & $\begin{array}{c}\text { Middle } \\
(4)\end{array}$ & $\begin{array}{c}\text { High } \\
(5)\end{array}$ \\
\cline { 2 - 6 } Mean education parental peers & $0.352^{* *}$ & -0.161 & -0.720 & 0.071 & -0.283 \\
& $(0.139)$ & $(0.340)$ & $(0.721)$ & $(0.455)$ & $(0.562)$ \\
Share high educated parental peers & & $1.687^{* *}$ & $3.518^{*}$ & 1.433 & 1.506 \\
Share low educated parental peers & & $(0.812)$ & $(1.800)$ & $(1.022)$ & $(1.269)$ \\
Mean education native peers & & -0.450 & 0.023 & -0.346 & -0.995 \\
& -0.290 & -0.249 & 0.092 & $-0.452^{*}$ & -0.278 \\
Year of birth FE & $(0.192)$ & $(0.193)$ & $(0.371)$ & $(0.230)$ & $(0.305)$ \\
Age at migration FE & $\sqrt{ }$ & $\sqrt{ }$ & $\sqrt{ }$ & $\sqrt{ }$ & $\sqrt{ }$ \\
\hline$N$ & $\sqrt{ }$ & $\sqrt{ }$ & $\sqrt{ }$ & $\sqrt{ }$ & $\sqrt{ }$ \\
$R^{2}$ & 3,253 & 3,253 & 540 & 2,023 & 690 \\
\hline
\end{tabular}

Source: Research Data Centres of the Federal Statistical Office and the Statistical Offices of the Länder, Microcensus (2007-2011), own calculations.

Notes: Linear probability models. Standard errors in parentheses, adjusted for clustering at the district/immigration-year level. The sample consists of children to at least one ethnic German parent whose both parents arrived not earlier than 1996 at child's age of 0-12 and who were of age 12-22 when observed in microcensus 2007-2011. Additionally the sample is restricted to those individuals affected by the modified "Assigned Place of Residence Act" according to Table 1. All regressions control for the subject's gender and the population size of immigrants from ethnic German origin countries in the respective district. Columns (1) and (2) additionally include dummies for parental education (three levels). Parents' education level is defined as 'low' if both father and mother hold no or only a lower secondary degree. We define parents to be 'highly' educated if at least one of the parents hold some tertiary degree. The remaining are defined as 'mid-educated'.

$* * *$ significant at $1 \% ; * *$ significant at $5 \%$; significant at $10 \%$. 
Table 5: Parental Peer Definition: Peers Originating from Same Country of Origin

Dependent variable: Tracking probability into upper secondary school

\begin{tabular}{lcccc}
\hline & & \multicolumn{3}{c}{ Split-Samples by Parental Education } \\
\cline { 2 - 5 } & Full & Low & Middle & High \\
& $(1)$ & $(2)$ & $(3)$ & -0.232 \\
\cline { 2 - 5 } Mean education co-ethnics & -0.135 & -0.722 & 0.034 & $(0.363)$ \\
Share high educated co-ethnics & $(0.185)$ & $(0.569)$ & $(0.232)$ & 0.569 \\
& 0.264 & $2.382 * *$ & -0.094 & $(0.775)$ \\
Share low educated co-ethnics & $(0.419)$ & $(1.204)$ & $(0.547)$ & -0.727 \\
& -0.416 & -0.804 & -0.335 & $(0.772)$ \\
Year of birth FE & $(0.353)$ & $(0.955)$ & $(0.436)$ & $\sqrt{ }$ \\
Age at migration FE & $\sqrt{ }$ & $\sqrt{ }$ & $\sqrt{ }$ & $\sqrt{ }$ \\
District FE & $\sqrt{ }$ & $\sqrt{ }$ & $\sqrt{ }$ & $\sqrt{ }$ \\
Ethnicity FE & $\sqrt{ }$ & $\sqrt{ }$ & $\sqrt{ }$ & 680 \\
\hline$N$ & 3,218 & 537 & 2,001 & 0.200 \\
$R^{2}$ & 0.136 & 0.212 & 0.116 & \\
\hline
\end{tabular}

Source: Research Data Centres of the Federal Statistical Office and the Statistical Offices of the Länder, Microcensus (2007-2011), own calculations.

Notes: Linear probability models. Standard errors in parentheses, adjusted for clustering at district/country-of-origin/immigration-year level. The sample consists of children to at least one ethnic German parent whose both parents arrived not earlier than 1996 at child's age of 0-12 and who were of age 12-22 when observed in microcensus 2007-2011. Additionally the sample is restricted to those individuals affected by the modified "Assigned Place of Residence Act" according to Table 1. Furthermore, the sample is restricted to individuals for whom the parental-peer-education measure is based on at least 10 observations (35 observations dropped). All regressions control for the subject's gender, the local population size of immigrants from the same origin country as the subject. Column (1) additionally includes dummies for parental education (three levels). Parents' education level is defined as 'low' if both father and mother hold no or only a lower secondary degree. We define parents to be 'highly' educated if at least one of the parents hold some tertiary degree. The remaining are defined as 'mid-educated'.

$* * *$ significant at $1 \% ; * *$ significant at $5 \% ; *$ significant at $10 \%$. 
Table 6: Robustness: Number of Observations in Peer Cells $>50$

Dependent variable: Tracking probability into upper secondary school

\begin{tabular}{lcccc}
\hline & & \multicolumn{3}{c}{ Split-Samples by Parental Education } \\
\cline { 2 - 5 } & $\begin{array}{c}\text { Full } \\
(1)\end{array}$ & $\begin{array}{c}\text { Low } \\
(2)\end{array}$ & $\begin{array}{c}\text { Middle } \\
(3)\end{array}$ & $\begin{array}{c}\text { High } \\
(4)\end{array}$ \\
\cline { 2 - 5 } Mean education co-ethnics & -0.055 & -0.907 & 0.243 & 0.116 \\
& $(0.239)$ & $(0.628)$ & $(0.277)$ & $(0.587)$ \\
Share high educated co-ethnics & 0.301 & $2.470^{*}$ & -0.324 & -0.205 \\
& $(0.589)$ & $(1.444)$ & $(0.693)$ & $(1.494)$ \\
Share low educated co-ethnics & -0.250 & -1.325 & -0.009 & 0.213 \\
& $(0.444)$ & $(1.093)$ & $(0.540)$ & $(1.079)$ \\
Year of birth FE & $\sqrt{ }$ & $\sqrt{ }$ & $\sqrt{ }$ & $\sqrt{ }$ \\
Age at migration FE & $\sqrt{ }$ & $\sqrt{ }$ & $\sqrt{ }$ & $\sqrt{ }$ \\
District FE & $\sqrt{ }$ & $\sqrt{ }$ & $\sqrt{ }$ & $\sqrt{ }$ \\
Ethnicity FE & 2,935 & 512 & 1,843 & 580 \\
\hline$N$ & 0.142 & 0.195 & 0.118 & 0.213 \\
$R^{2}$ & & & $\sqrt{ }$ & \\
\hline
\end{tabular}

Source: Research Data Centres of the Federal Statistical Office and the Statistical Offices of the Länder, Microcensus (2007-2011), own calculations.

Notes: Linear probability models. Standard errors in parentheses, adjusted for clustering at district/country-of-origin/immigration-year level. Here: sample restricted to individuals for whom the parental-peer-education measure is based on at least 50 observations ( 318 observations dropped). Covariates according to Table 5.

$* * *$ significant at $1 \%$; * significant at $5 \%$; significant at $10 \%$. 
Table 7: Robustness: Anpassungsschicht

Dependent variable: Tracking probability into upper secondary school

\begin{tabular}{lcccc}
\hline & & \multicolumn{3}{c}{ Split-Samples by Parental Education } \\
\cline { 2 - 5 } & $\begin{array}{c}\text { Full } \\
(1)\end{array}$ & $\begin{array}{c}\text { Low } \\
(2)\end{array}$ & $\begin{array}{c}\text { Middle } \\
(3)\end{array}$ & $\begin{array}{c}\text { High } \\
(4)\end{array}$ \\
\cline { 2 - 5 } Mean education co-ethnics & -0.050 & -0.170 & 0.055 & -0.184 \\
& $(0.118)$ & $(0.218)$ & $(0.158)$ & $(0.334)$ \\
Share high educated co-ethnics & 0.128 & $1.656^{* * *}$ & -0.049 & 0.575 \\
& $(0.289)$ & $(0.627)$ & $(0.381)$ & $(0.762)$ \\
Share low educated co-ethnics & -0.124 & 0.315 & -0.163 & 0.308 \\
& $(0.226)$ & $(0.397)$ & $(0.281)$ & $(0.689)$ \\
Year of birth FE & $\sqrt{ }$ & $\sqrt{ }$ & $\sqrt{ }$ & $\sqrt{ }$ \\
Age at migration FE & $\sqrt{ }$ & $\sqrt{ }$ & $\sqrt{ }$ & $\sqrt{ }$ \\
Anpassungsschicht FE & $\sqrt{ }$ & $\sqrt{ }$ & $\sqrt{ }$ & $\sqrt{ }$ \\
Ethnicity FE & 3,026 & 517 & 1,896 & 613 \\
\hline$N$ & 0.163 & 0.339 & 0.161 & 0.288 \\
$R^{2}$ & & & & \\
\hline
\end{tabular}

Source: Research Data Centres of the Federal Statistical Office and the Statistical Offices of the Länder, Microcensus (2007-2011), own calculations.

Notes: Linear probability models. Standard errors in parentheses, adjusted for clustering at Anpassungsschicht/country-of-origin/immigrationyear level. Sample and covariates according to Table 5.

$* * *$ significant at $1 \%$;** significant at $5 \%$; significant at $10 \%$. 
Table 8: Who Parents Learn From: Co-ethnic vs. Non-co-ethnic Peers

Dependent variable: Tracking probability into upper secondary school

\begin{tabular}{|c|c|c|c|c|}
\hline & \multirow[b]{2}{*}{$\begin{array}{c}\text { Full } \\
(1)\end{array}$} & \multicolumn{3}{|c|}{ Split-Samples by Parental Education } \\
\hline & & $\begin{array}{c}\text { Low } \\
(2)\end{array}$ & $\begin{array}{c}\text { Middle } \\
\text { (3) }\end{array}$ & $\begin{array}{l}\text { High } \\
(4)\end{array}$ \\
\hline Mean education co-ethnics & $\begin{array}{l}-0.126 \\
(0.192)\end{array}$ & $\begin{array}{l}-0.700 \\
(0.567)\end{array}$ & $\begin{array}{c}0.174 \\
(0.238)\end{array}$ & $\begin{array}{c}-0.340 \\
(0.384)\end{array}$ \\
\hline Mean education non co-ethnics & $\begin{array}{c}0.060 \\
(0.284)\end{array}$ & $\begin{array}{c}0.002 \\
(0.372)\end{array}$ & $\begin{array}{c}0.661 \\
(0.409)\end{array}$ & $\begin{array}{l}-0.765 \\
(0.692)\end{array}$ \\
\hline Share high educated co-ethnics & $\begin{array}{c}0.243 \\
(0.435)\end{array}$ & $\begin{array}{c}2.402 * * \\
(1.203)\end{array}$ & $\begin{array}{l}-0.365 \\
(0.552)\end{array}$ & $\begin{array}{c}0.603 \\
(0.763)\end{array}$ \\
\hline Share high educated non co-ethnics & $\begin{array}{c}-0.156 \\
(1.236)\end{array}$ & $\begin{array}{c}1.005 \\
(3.345)\end{array}$ & $\begin{array}{l}-1.064 \\
(1.562)\end{array}$ & $\begin{array}{c}-0.549 \\
(3.108)\end{array}$ \\
\hline Share low educated co-ethnics & $\begin{array}{c}-0.401 \\
(0.366)\end{array}$ & $\begin{array}{c}-0.731 \\
(0.968)\end{array}$ & $\begin{array}{l}-0.125 \\
(0.459)\end{array}$ & $\begin{array}{c}-0.998 \\
(0.806)\end{array}$ \\
\hline Share low educated non co-ethnics & $\begin{array}{c}0.199 \\
(1.068)\end{array}$ & $\begin{array}{c}0.931 \\
(2.224)\end{array}$ & $\begin{array}{c}1.776 \\
(1.169)\end{array}$ & $\begin{array}{l}-4.194 \\
(2.804)\end{array}$ \\
\hline $\begin{array}{l}\text { Year of birth FE } \\
\text { Age at migration FE } \\
\text { District FE } \\
\text { Ethnicity FE } \\
\end{array}$ & $\begin{array}{l}\sqrt{ } \\
\sqrt{ } \\
\sqrt{ } \\
\sqrt{ }\end{array}$ & $\begin{array}{l}\sqrt{ } \\
\sqrt{ } \\
\sqrt{ } \\
\sqrt{ }\end{array}$ & $\begin{array}{l}\sqrt{ } \\
\sqrt{ } \\
\sqrt{ } \\
\sqrt{ }\end{array}$ & $\begin{array}{l}\sqrt{ } \\
\sqrt{ } \\
\sqrt{ } \\
\sqrt{ }\end{array}$ \\
\hline$N$ & 3,218 & 537 & 2,001 & 680 \\
\hline$R^{2}$ & 0.136 & 0.213 & 0.119 & 0.208 \\
\hline
\end{tabular}

Source: Research Data Centres of the Federal Statistical Office and the Statistical Offices of the Länder, Microcensus (2007-2011), own calculations.

Notes: Linear probability models. Standard errors in parentheses, adjusted for clustering at district/country-of-origin/immigration-year level. Sample and covariates according to Table 5 .

*** significant at $1 \%$;* significant at $5 \%$; significant at $10 \%$. 
Table 9: Parental Learning: Adult Peers without Children

Dependent variable: Tracking probability into upper secondary school

\begin{tabular}{|c|c|c|c|c|}
\hline & \multirow[b]{2}{*}{$\begin{array}{l}\text { Full } \\
(1)\end{array}$} & \multicolumn{3}{|c|}{ Split-Samples by Parental Education } \\
\hline & & $\begin{array}{c}\text { Low } \\
(2)\end{array}$ & $\begin{array}{c}\text { Middle } \\
\text { (3) }\end{array}$ & $\begin{array}{l}\text { High } \\
(4)\end{array}$ \\
\hline Mean education co-ethnics & $\begin{array}{c}0.067 \\
(0.154)\end{array}$ & $\begin{array}{l}-0.542 \\
(0.392)\end{array}$ & $\begin{array}{c}0.099 \\
(0.207)\end{array}$ & $\begin{array}{c}0.223 \\
(0.310)\end{array}$ \\
\hline Share high educated co-ethnics & $\begin{array}{l}-0.290 \\
(0.353)\end{array}$ & $\begin{array}{l}1.461 * \\
(0.792)\end{array}$ & $\begin{array}{l}-0.369 \\
(0.491)\end{array}$ & $\begin{array}{c}-0.658 \\
(0.747)\end{array}$ \\
\hline Share low educated co-ethnics & $\begin{array}{l}-0.107 \\
(0.317)\end{array}$ & $\begin{array}{c}-0.921 \\
(0.833)\end{array}$ & $\begin{array}{l}-0.187 \\
(0.419)\end{array}$ & $\begin{array}{c}0.055 \\
(0.600)\end{array}$ \\
\hline $\begin{array}{l}\text { Year of birth FE } \\
\text { Age at migration FE } \\
\text { District FE } \\
\text { Ethnicity FE }\end{array}$ & $\begin{array}{l}\sqrt{ } \\
\sqrt{ } \\
\sqrt{ } \\
\sqrt{ }\end{array}$ & $\begin{array}{l}\sqrt{ } \\
\sqrt{ } \\
\sqrt{ } \\
\sqrt{ }\end{array}$ & $\begin{array}{l}\sqrt{ } \\
\sqrt{ } \\
\sqrt{ } \\
\sqrt{ }\end{array}$ & $\begin{array}{l}\sqrt{ } \\
\sqrt{ } \\
\sqrt{ } \\
\sqrt{ }\end{array}$ \\
\hline $\begin{array}{l}N \\
R^{2}\end{array}$ & $\begin{array}{l}3,159 \\
0.140\end{array}$ & $\begin{array}{c}536 \\
0.212\end{array}$ & $\begin{array}{l}1,967 \\
0.115\end{array}$ & $\begin{array}{c}656 \\
0.199\end{array}$ \\
\hline
\end{tabular}

Source: Research Data Centres of the Federal Statistical Office and the Statistical Offices of the Länder, Microcensus (2007-2011), own calculations.

Notes: Linear probability models. Standard errors in parentheses, adjusted for clustering at district/country-of-origin/immigration-year level. Peer measures are constructed excluding adults with children in the age-range 0-16. Sample and covariates according to Table 5. *** significant at $1 \%$;* significant at $5 \%$; significant at $10 \%$. 
Table 10: Polarization

Dependent variable: Tracking probability into upper secondary school

Sample of low-educated parents:

Sub-Samples according to degree of polarization

\begin{tabular}{|c|c|c|c|}
\hline & $\begin{array}{l}\text { share mid edu } \\
\text { peers }<=20 \% \\
\text { (1) }\end{array}$ & $\begin{array}{c}\text { share lo edu } \\
\text { peers }>=40 \% \\
\text { (2) }\end{array}$ & $\begin{array}{c}\text { above/equal median } \\
\text { polarization index } \\
\text { (3) }\end{array}$ \\
\hline Mean education co-ethnics & $\begin{array}{c}-0.764 \\
(0.737)\end{array}$ & $\begin{array}{l}-0.445 \\
(1.689)\end{array}$ & $\begin{array}{c}-0.754 \\
(0.649)\end{array}$ \\
\hline Share high educated co-ethnics & $\begin{array}{c}3.221 * * \\
(1.520)\end{array}$ & $\begin{array}{c}2.739 \\
(3.273)\end{array}$ & $\begin{array}{c}3.303 * * \\
(1.358)\end{array}$ \\
\hline Share low educated co-ethnics & $\begin{array}{c}0.428 \\
(0.949)\end{array}$ & $\begin{array}{l}-0.597 \\
(2.915)\end{array}$ & $\begin{array}{c}-0.588 \\
(0.878)\end{array}$ \\
\hline $\begin{array}{l}\text { Year of birth FE } \\
\text { Age at migration FE } \\
\text { District FE } \\
\text { Ethnicity FE } \\
\end{array}$ & $\begin{array}{l}\sqrt{ } \\
\sqrt{ } \\
\sqrt{ } \\
\sqrt{ }\end{array}$ & $\begin{array}{l}\sqrt{ } \\
\sqrt{ } \\
\sqrt{ } \\
\sqrt{ }\end{array}$ & $\begin{array}{l}\sqrt{ } \\
\sqrt{ } \\
\sqrt{ } \\
\sqrt{ }\end{array}$ \\
\hline$N$ & 302 & 232 & 292 \\
\hline$R^{2}$ & 0.327 & 0.248 & 0.301 \\
\hline
\end{tabular}

Source: Research Data Centres of the Federal Statistical Office and the Statistical Offices of the Länder, Microcensus (2007-2011), own calculations.

Notes: Linear probability models. Standard errors in parentheses, adjusted for clustering at district/country-of-origin/immigration-year level. Covariates according to Table 5 .

*** significant at $1 \%$;* significant at $5 \%$; significant at $10 \%$. 
Table 11: Gender

Dependent variable: Tracking probability into upper secondary school

\begin{tabular}{|c|c|c|c|c|}
\hline & \multicolumn{4}{|c|}{ Sample: Low-educated parents } \\
\hline & $\begin{array}{l}\text { Male } \\
\text { (1) }\end{array}$ & $\begin{array}{c}\text { Female } \\
\text { (2) }\end{array}$ & $\begin{array}{l}\text { Male } \\
\text { (3) }\end{array}$ & $\begin{array}{c}\text { Female } \\
\text { (4) }\end{array}$ \\
\hline Mean education male co-ethnics & $\begin{array}{l}-0.314 \\
(0.658)\end{array}$ & $\begin{array}{c}0.257 \\
(0.644)\end{array}$ & & \\
\hline Share high educated male co-ethnics & $\begin{array}{c}0.456 \\
(1.534)\end{array}$ & $\begin{array}{c}0.120 \\
(1.707)\end{array}$ & & \\
\hline Share low educated male co-ethnics & $\begin{array}{l}-0.589 \\
(1.015)\end{array}$ & $\begin{array}{c}0.415 \\
(0.949)\end{array}$ & & \\
\hline Mean education female co-ethnics & & & $\begin{array}{c}-0.840 \\
(0.650)\end{array}$ & $\begin{array}{c}-0.594 \\
(0.574)\end{array}$ \\
\hline Share high educated female co-ethnics & & & $\begin{array}{c}1.935 \\
(1.497)\end{array}$ & $\begin{array}{l}2.323^{*} \\
(1.364)\end{array}$ \\
\hline Share low educated female co-ethnics & & & $\begin{array}{c}-0.706 \\
(1.474)\end{array}$ & $\begin{array}{c}-0.747 \\
(1.166)\end{array}$ \\
\hline $\begin{array}{l}\text { Year of birth FE } \\
\text { Age at migration FE } \\
\text { District FE } \\
\text { Ethnicity FE }\end{array}$ & $\begin{array}{l}\sqrt{ } \\
\sqrt{ } \\
\sqrt{ } \\
\sqrt{ }\end{array}$ & $\begin{array}{l}\sqrt{ } \\
\sqrt{ } \\
\sqrt{ } \\
\sqrt{ }\end{array}$ & $\begin{array}{l}\sqrt{ } \\
\sqrt{ } \\
\sqrt{ } \\
\sqrt{ }\end{array}$ & $\begin{array}{l}\sqrt{ } \\
\sqrt{ } \\
\sqrt{ } \\
\sqrt{ }\end{array}$ \\
\hline $\begin{array}{l}N \\
R^{2}\end{array}$ & $\begin{array}{c}296 \\
0.285\end{array}$ & $\begin{array}{c}234 \\
0.331\end{array}$ & $\begin{array}{c}296 \\
0.294\end{array}$ & $\begin{array}{c}239 \\
0.357\end{array}$ \\
\hline
\end{tabular}

Source: Research Data Centres of the Federal Statistical Office and the Statistical Offices of the Länder, Microcensus (2007-2011), own calculations.

Notes: Linear probability models. Standard errors in parentheses, adjusted for clustering at district/country-of-origin/immigration-year level. Covariates according to Table 5 .

*** significant at $1 \%$; ** significant at $5 \%$; significant at $10 \%$. 


\section{Appendix}

Figure A1: Intergenerational Education-persistence among Aussiedler Immigrants in Germany

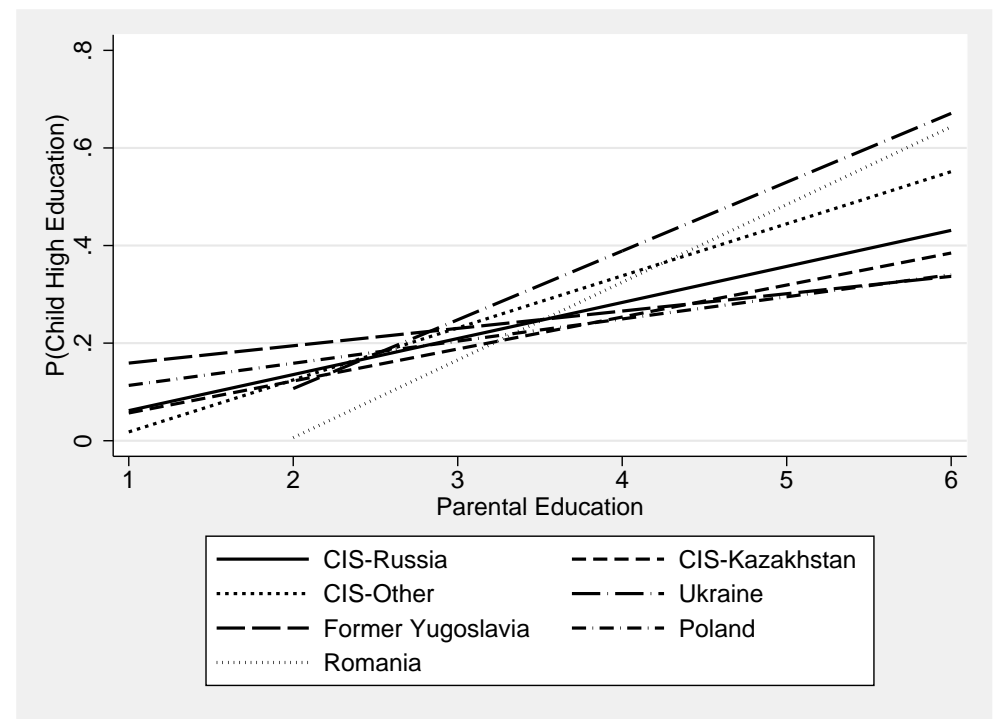

Source: Research Data Centres of the Federal Statistical Office and the Statistical Offices of the Länder, Microcensus (2007-2011), own calculations.

Notes: Tracking probability of an Aussiedler child immigrant into upper secondary school as a linear function of parental education, estimated separately by ethnic group. Parents' education level is defined as the highest ISCED level among parents. ISCED-levels: (1) no secondary degree, drop-out; (2) lower secondary degree; (3) upper secondary degree; (4) post-secondary, non-tertiary degree; (5) short-cycle tertiary degree; (6) tertiary degree. Sample as in main analysis (see Section 4 and notes to Table 5). 
Figure A2: Ethnic Capital and Educational Attainment among Aussiedler Children

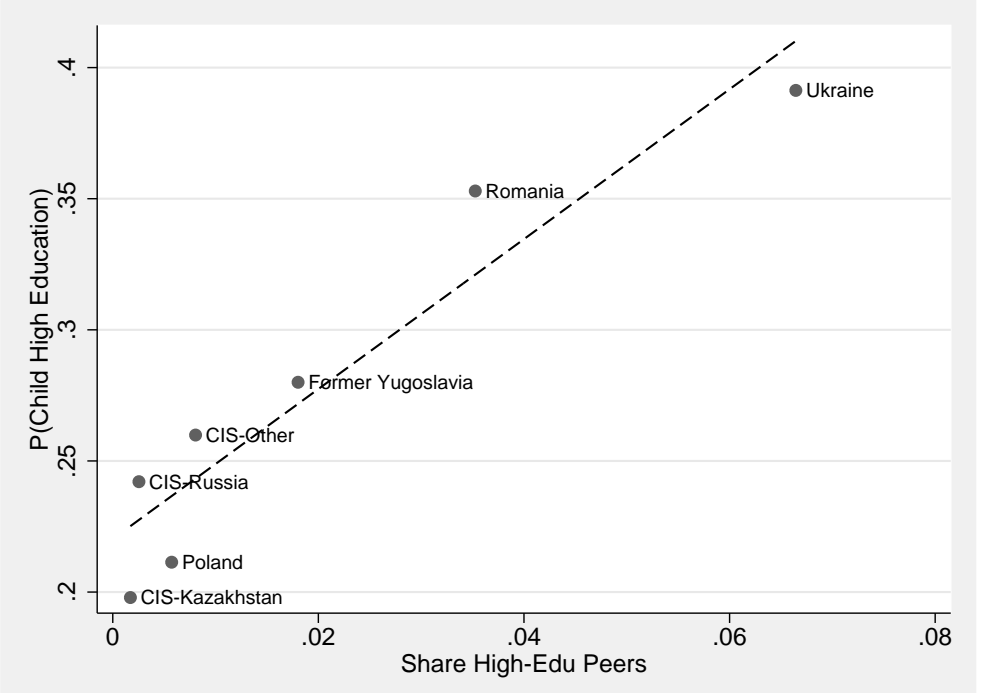

Source: Research Data Centres of the Federal Statistical Office and the Statistical Offices of the Länder, Microcensus (2007-2011), own calculations.

Notes: Tracking probability of an Aussiedler child immigrant into upper secondary school as a linear function of national fraction of high educated among co-ethnic peers. Sample as in main analysis (see Section 4 and notes to Table 5). 
Table A1: Economic Reason to Migrate by Immigration Status

\begin{tabular}{llrr}
\hline & Mean & Std.Dev. & \multicolumn{1}{c}{$N$} \\
\hline Asylum seeker & $0.069^{*}$ & 0.254 & 247 \\
Ethnic German & 0.130 & 0.336 & 1,158 \\
Other & 0.144 & 0.351 & 987 \\
\hline Total & 0.129 & 0.335 & 2,392 \\
\hline Subsample: age & at migration $>18$ \\
\hline Asylum seeker & $0.079^{*}$ & 0.271 & 177 \\
Ethnic German & 0.177 & 0.382 & 789 \\
Other & 0.167 & 0.373 & 690 \\
\hline Total & 0.162 & 0.369 & 1,656 \\
\hline
\end{tabular}

Source: SOEP 1994-2009, own calculations.

Notes: The variable economic reason to migrate stems from the SOEP biography questionnaire and equals one when migrant states that "I wanted to work and earn money in Germany to support my family and save money". Each SOEP respondent answers the biographical questionnaire only once (at first contact).

* Statistically different from other-immigrant mean at

5 percent confidence level. 
Table A2: Very Good German Language Skills by Immigration Status

\begin{tabular}{llll}
\hline & Mean & Std.Dev. & $N$ \\
\hline Oral skills & & & \\
\hline Asylum seeker & $0.237 *$ & 0.427 & 118 \\
Ethnic German & 0.357 & 0.480 & 465 \\
Other & 0.349 & 0.477 & 539 \\
\hline Total & 0.340 & 0.474 & 1,122 \\
\hline Written skills & & & \\
\hline Asylum seeker & 0.203 & 0.404 & 118 \\
Ethnic German & 0.289 & 0.453 & 462 \\
Other & 0.277 & 0.448 & 538 \\
\hline Total & 0.274 & 0.446 & 1,118 \\
\hline
\end{tabular}

Source: SOEP 2003, own calculations.

Notes: * Statistically different from other-immigrant mean at 5 percent confidence level. 